\title{
Sulfur, carbon, and nitrogen cycling in faunated marine sediments impacted by repeated organic enrichment
}

\author{
T. Valdemarsen*, E. Kristensen, M. Holmer \\ Institute of Biology, University of Southern Denmark, 5230 Odense M, Denmark
}

\begin{abstract}
The effects of organic enrichment on sediment biogeochemistry were studied in sediment mesocosms with indigenous populations of infauna. Two types of sediments, differing in content of reactive $\mathrm{Fe}$, were subjected to weekly pulses of labile organic matter (fish feed), corresponding to an average organic loading of $\sim 350 \mathrm{C} \mathrm{m}^{-2} \mathrm{~d}^{-1}$ and $\sim 50 \mathrm{mmol} \mathrm{N} \mathrm{m} \mathrm{d}^{-2} \mathrm{~d}^{-1}$ for a period of $65 \mathrm{~d}$. The aims of this experiment were 3 -fold: (1) to study the metabolic capacity for organic $\mathrm{C}$ and $\mathrm{N}$ mineralization at the sediment-water interface; (2) to study the impact of organic enrichment on spatial and temporal sulfide accumulation; and (3) to estimate the importance of Fe-driven sulfide buffering for sulfide accumulation. Organic enrichment stimulated solute exchange between sediment and water within $10 \mathrm{~d}$, resulting in 5 to 8 times stimulated $\mathrm{O}_{2}$ uptake and $\mathrm{CO}_{2}$ efflux, indicating a fast response time of surface-associated microbial consortia. Both ${ }^{35} \mathrm{~S}_{-} \mathrm{SO}_{4}{ }^{2-}$ radiotracer essays and sulfide microprofiles confirmed that added organic matter was primarily oxidized by sulfate reduction. However, despite high sulfate reduction of up to $70 \mathrm{mmol} \mathrm{m}^{-2} \mathrm{~d}^{-1}$, sulfide only accumulated to $1-2 \mathrm{mM}$ in the upper $2 \mathrm{~cm}$ of enriched cores. In Fe-poor sediment, produced sulfide was reoxidized with $\mathrm{O}_{2}$ or $^{\mathrm{NO}_{3}}$ at the sediment-water interface, whereas in Fe-rich sediment, sulfide was oxidized with $\mathrm{O}_{2}, \mathrm{NO}_{3}{ }^{-}$, or Fe oxides in a $<2 \mathrm{~mm}$ thick suboxic zone or precipitated with dissolved $\mathrm{Fe}^{2+}$. By the end, up to 92 and $100 \%$ of added organic C and N, respectively, was mineralized, suggesting a high metabolic capacity for organic matter mineralization in faunated sediments. Furthermore, whereas sulfide precipitation was insignificant in low-Fe sediment, up to $63 \%$ of sulfide precipitated with $\mathrm{Fe}^{2+}$ in high-Fe sediment, suggesting a high capacity for sulfide mitigation in faunated Fe-rich sediment.
\end{abstract}

KEY WORDS: Sulfide buffering - Benthic fluxes - Decomposition - Eutrophication - Fish feed . Sulfate reduction

Resale or republication not permitted without written consent of the publishe

\section{INTRODUCTION}

The commonly observed up to 25 times increased sedimentation of organic matter (OM) in marine areas affected by eutrophication and aquaculture (Giles et al. 2006, Holmer et al. 2007, Kutti et al. 2007, 2008) stimulates benthic metabolism primarily through carbon (C) oxidation via sulfate reduction (SR). SR can account for all $\mathrm{C}$ oxidation in organically enriched sediments and may be enhanced 5 to 10 times when compared to unaffected reference sites (Holmer et al. 2002, Holmer \& Frederiksen 2007). As a consequence, toxic sulfide accumulates to $\mathrm{mM}$ levels in sediment pore- waters (Macleod et al. 2004, Porrello et al. 2005), which may have negative consequences for benthic communities (Hargrave et al. 2008, Mascaro et al. 2009). Correlations between sedimentation rates and infaunal diversity or production suggest that most benthic animals remain unaffected until an upper OM loading threshold of 100 to $400 \mathrm{mmol} \mathrm{C} \mathrm{m}^{-2} \mathrm{~d}^{-1}$ (Findlay \& Watling 1997, Hargrave et al. 2008, Kutti et al. 2008). However, site-specific factors such as water currents, sediment structure, and composition as well as indigenous infauna may significantly influence this threshold, and a more detailed understanding of the controls of SR and accumulation of total dissolved sulfide 
$\left(\mathrm{TH}_{2} \mathrm{~S}=\mathrm{H}_{2} \mathrm{~S}+\mathrm{HS}^{-}+\mathrm{S}^{2-}\right)$ in organically enriched sediments is desirable.

OM deposited in areas impacted by eutrophication or aquaculture is primarily derived from phytoplankton debris, fecal matter, or excess fish feed. The majority is labile and can be easily degraded under anoxic conditions (Holmer \& Kristensen 1994a,b, Kristensen \& Holmer 2001) leaving only a small fraction to degrade slowly or be permanently buried (Canfield 1994). Hence benthic metabolism and SR is often stimulated in direct proportion to sedimentation rates (Findlay \& Watling 1997). $\mathrm{TH}_{2} \mathrm{~S}$ accumulation is counteracted by oxidation or precipitation. $\mathrm{TH}_{2} \mathrm{~S}$ oxidation occurs in close proximity to $\mathrm{O}_{2}$ (e.g. interfaces at the sediment surface or within infauna burrows) (Kristensen 2000), where it is oxidized to non-toxic sulfur species (e.g. $\mathrm{S}^{0}$ and $\mathrm{SO}_{4}{ }^{2-}$ ) with $\mathrm{O}_{2}, \mathrm{NO}_{3}{ }^{-}$, or iron (Fe) and manganese $(\mathrm{Mn})$ oxides (Schippers \& Jørgensen 2002). In organically enriched sediment, $\mathrm{TH}_{2} \mathrm{~S}$ may ultimately diffuse to the surface where it is oxidized biologically or chemically within a $<1 \mathrm{~mm}$ overlap zone between $\mathrm{TH}_{2} \mathrm{~S}$ and $\mathrm{O}_{2}$ (Tankere et al. 2002, Canfield et al. 2005, Sayama et al. 2005, Preisler et al. 2007). Alternatively, $\mathrm{TH}_{2} \mathrm{~S}$ is removed from solution by precipitation with dissolved $\mathrm{Fe}^{2+}$ to form reduced $\mathrm{Fe}$ sulfides (e.g. $\mathrm{FeS}$ and $\mathrm{FeS}_{2}$ ) as long as $\mathrm{Fe}^{2+}$ is available (Rickard 1995, Rickard \& Morse 2005, Giordani et al. 2008). Fedriven $\mathrm{TH}_{2} \mathrm{~S}$ buffering has been shown to significantly hamper $\mathrm{TH}_{2} \mathrm{~S}$ buildup and reduce sediment oxygen uptake (SOU) in eutrophic coastal sediments (Heijs et al. 1999, 2000, Valdemarsen et al. 2009).

Bioturbation affects $\mathrm{C}$ and $\mathrm{S}$ cycling in marine sediments through irrigation and sediment reworking. While irrigation translocates oxygen into otherwise anoxic sediment (Kristensen 2001, Nielsen et al. 2003), reworking mediates downward mixing of surfacedeposited OM into deeper anoxic layers and vice versa (Aller 1994, Kristensen \& Mikkelsen 2003, Papaspyrou et al. 2004). Irrigation is thus frequently linked to enhanced OM mineralization, whereas reworking activities have been linked to both enhanced mineralization of indigenous $\mathrm{OM}$ and hampered mineralization of recently deposited OM (Aller \& Aller 1998, Kristensen \& Holmer 2001). The impact of bioturbation on $\mathrm{S}$ cycling in organically enriched sediments is not well documented. The rapid oxidation of total reduced inorganic sulfides (TRIS) observed upon introduction of infauna suggests that bioturbation is vital for regeneration of the $\mathrm{TH}_{2} \mathrm{~S}$ buffering capacity (Heilskov \& Holmer 2003, Nielsen et al. 2003). Furthermore, irrigation may lower the importance of SR for total C oxidation (Banta et al. 1999, Heilskov \& Holmer 2001, 2003) and TRIS precipitation may thus be lower in faunated as opposed to defaunated sediments (Chareonpanich et al. 1994, Banta et al. 1999).
The effects of OM enrichment on $\mathrm{S}, \mathrm{C}$, and nitrogen (N) cycling have been extensively studied in sediment microcosms. In these studies, the entire sediment matrix has usually been uniformly enriched (Kristensen \& Hansen 1995, Sloth et al. 1995, Hansen \& Kristensen 1998, Banta et al. 1999) or OM was added as a single pulse to the sediment surface (Sloth et al. 1995, Pedersen et al. 1999, Kristensen \& Mikkelsen 2003, Papaspyrou et al. 2004, Karle et al. 2007). Although these studies have provided knowledge on the general impacts of organic enrichment, they cannot simulate the behavior of e.g. $\mathrm{SR}_{1} \mathrm{TH}_{2} \mathrm{~S}$ buffering, and metabolic capacity where OM enrichment is continuous. Thus, Valdemarsen et al. (2009) found that stimulation of SR and accumulation of $\mathrm{TH}_{2} \mathrm{~S}$ and TRIS was restricted to the enriched surface layer in defaunated sediments enriched with OM pulses. Furthermore, they found a highly dynamic decay pattern in contrast to the gradual attenuation observed when $\mathrm{OM}$ is added as a single pulse (e.g. Hansen \& Kristensen 1998).

In the present study we investigated the effects of $\mathrm{OM}$ pulses on SR, benthic metabolism, and Fe-sulfide dynamics in sediment mesocosms with indigenous populations of infauna. Two types of organically poor sediments, differing mainly in Fe content, were exposed to weekly pulses of OM for $9 \mathrm{wk}$. Benthic metabolism was determined as the sediment-water exchange of total $\mathrm{CO}_{2}\left(\mathrm{TCO}_{2}=\mathrm{CO}_{2}+\mathrm{H}_{2} \mathrm{CO}_{3}+\mathrm{HCO}_{3}^{-}+\mathrm{CO}_{3}{ }^{-2}\right), \mathrm{NH}_{4}{ }^{+}, \mathrm{O}_{2}$, $\mathrm{Fe}^{2+}$, and $\mathrm{TH}_{2} \mathrm{~S}$. SR was measured by radiotracer measurements, and small-scale spatial and temporal changes in sulfide accumulation were determined by microelectrodes. Fe and S budgets provided the basis for estimates of iron-driven sulfide buffering as well as rates of sulfide oxidation and TRIS formation. $\mathrm{C}$ and $\mathrm{N}$ budgets provided evidence for the efficiency of OM degradation at the sediment-water interface. Furthermore, by comparison with Valdemarsen et al. (2009), we draw conclusions about the impact of infauna on S, C, and $\mathrm{N}$ cycling in organically enriched sediments.

\section{MATERIALS AND METHODS}

Sediment handling and experimental setup. Sediment was collected in September 2006 at 2 sites located along the west coast of the island of Fyn, Denmark. Sediment consisting of medium sand with a low content of $\mathrm{Fe}$ and $\mathrm{OM}$ was collected at Svenstrup Strand (Fe-poor), while sediment with similar grain size structure, but relatively rich in Fe and OM, was collected at Odden (Fe-rich) close to Fænø Sund. The 2 sites are situated $<5 \mathrm{~km}$ apart and share the same body of water. Location of sampling sites can be seen in Valdemarsen et al. (2009). At each site, 9 undisturbed sediment cores containing the natural benthic fauna 
were collected in shallow water (about $1 \mathrm{~m}$ depth) with Plexiglas core liners (inner diameter [i.d.] $8 \mathrm{~cm}$ ) that were sealed at both ends with rubber stoppers. Additionally, subsamples of the upper $10 \mathrm{~cm}$ sediment for the determination of grain size and average sediment characteristics were collected at each site, sieved through $1 \mathrm{~mm}$ mesh and homogenized by hand. Water temperature and salinity on the day of sampling were $15^{\circ} \mathrm{C}$ and 20 , respectively, at both sites.

In the laboratory, cores were adjusted to a depth of $20 \mathrm{~cm}$ leaving a $10 \mathrm{~cm}$ water column. The 9 cores from each sampling site were divided into 2 groups: 6 cores served as unmanipulated controls (control) and 3 cores were designated for enrichment with labile OM (enriched). Fe-poor and Fe-rich controls were placed in one tank, and the remaining 3 cores from each site were placed in another tank. Each tank contained 701 of salinity 20 filtered seawater from the Fe-poor site. Cores were arranged around a central magnet rotating at $60 \mathrm{rpm}$ and were equipped with $4 \mathrm{~cm}$ long magnetic stirring bars located a few $\mathrm{cm}$ above the sediment surface. The water reservoir in each tank was mixed and aerated by air pumps, and cores were continuously open to the shared water reservoir, except during flux incubations. The cores were kept in darkness at $15^{\circ} \mathrm{C}$, and $20 \%$ of the water in each tank was replaced weekly to avoid accumulation of metabolites in the water phase.

Cores were allowed to stabilize for $14 \mathrm{~d}$, after which the experiment was initiated. This point is hereafter referred to as $t=0$. Enriched cores received weekly pulses of labile OM in the form of commercial fish feed (Ecolife, Dansk Ørredfoder; C and N content of 49.4 and $1.22 \%$, respectively). The enrichment procedure was identical to that of Valdemarsen et al. (2009) with respect to OM quality, quantity, and pulse frequency. Homogenized fish feed $(0.29 \mathrm{~g})$ was thoroughly mixed into $10 \mathrm{~g}$ of homogenized Fe-poor or Fe-rich sediment corresponding to a $1 \mathrm{~mm}$ thick layer of sediment after application. The enriched sediment pellet was applied directly to the surface of the cores with a spatula after removing the water phase. Cores were gently refilled with water, avoiding resuspension, and returned to the incubation tanks. The enrichment procedure was performed once a week throughout the experiment, and average organic $\mathrm{C}(\mathrm{OC})$ and $\mathrm{N}(\mathrm{ON})$ loading from the first enrichment to the end of the experiment was 357 and $50.3 \mathrm{mmol} \mathrm{m}^{-2} \mathrm{~d}^{-1}$ in Fe-poor cores, and 329 and $46.5 \mathrm{mmol} \mathrm{m}^{-2} \mathrm{~d}^{-1}$ in Fe-rich cores, respectively. Thus, the simulated organic loading rates were comparable to the range of sedimentation rates reported from beneath fish farms or mussel rafts (e.g. Giles et al. 2006, Holmer et al. 2007).

Solute exchange between sediment and water. Effluxes of metabolites $\left(\mathrm{TCO}_{2}\right.$, dissolved organic car- bon [DOC], $\mathrm{NH}_{4}{ }^{+}, \mathrm{TH}_{2} \mathrm{~S}$, and $\mathrm{Fe}^{2+}$ ) were determined on 3 enriched cores and 3 control cores twice a week. The frequency of flux measurements in control cores was reduced to once a week after $20 \mathrm{~d}$. Initial water samples were taken from each core, which were subsequently closed with rubber stoppers. Enriched cores were incubated for $2 \mathrm{~h}$ and control cores for $5 \mathrm{~h}$ before the rubber stoppers were removed and final water samples were taken. Samples were preserved, stored, and analyzed according to the procedures described below. Changes in $\mathrm{O}_{2}$ concentration during incubations were detected by an Ox100 mini electrode (Unisense).

The irrigation activity of resident infauna was determined by incubating cores for about $24 \mathrm{~h}$ in seawater containing $\sim 10 \mathrm{mM} \mathrm{Br}^{-}$prior to the final sectioning (Heilskov et al. 2006). Bioirrigation intensity was calculated from the diffusion-corrected macrofaunainduced increase in the depth-integrated inventory of porewater $\mathrm{Br}^{-}$.

Microprofiles of $\mathrm{O}_{2}, \mathbf{p H}$, and $\mathbf{H}_{2} \mathrm{~S}$. Vertical profiles of $\mathrm{O}_{2}, \mathrm{H}_{2} \mathrm{~S}$, and $\mathrm{pH}$ were measured once a week, usually $5 \mathrm{~d}$ after the enrichment procedure, throughout the experiment in both control and enriched cores. Profiles were measured in 1 to 3 replicate cores (usually 1 core chosen at random) from each series, and usually $5 \mathrm{O}_{2}$ profiles and $3 \mathrm{H}_{2} \mathrm{~S}$ and $\mathrm{pH}$ profiles were recorded at random positions within each core. Profiles were measured using Unisense glass minielectrodes Ox-100, $\mathrm{H}_{2} \mathrm{~S}-100$, and $\mathrm{pH}-100$, with a tip diameter of $100 \mu \mathrm{m}$. Data from the $\mathrm{O}_{2}$ and $\mathrm{H}_{2} \mathrm{~S}$ sensor were detected by a Unisense picoammeter (pA2000) and data from the $\mathrm{pH}$ electrode were detected with a Knick Portamess $911 \mathrm{pH}$ voltmeter. $\mathrm{O}_{2}$ profiles were converted to concentration after a 2-point calibration $(100 \%$ and $0 \%$ $\mathrm{O}_{2}$ ) (Glud et al. 2000). The $\mathrm{pH}$ electrode was calibrated in standard buffer solutions $(\mathrm{pH}=4$ and 7 ) before use. The $\mathrm{H}_{2} \mathrm{~S}$ sensor was calibrated in $\mathrm{N}_{2}$-purged $50 \mathrm{mM}$ HEPES buffer (adjusted to $\mathrm{pH}=7.00$ ) to which $0.02 \mathrm{M}$ $\mathrm{TH}_{2} \mathrm{~S}$ stock solution prepared from $\mathrm{Na}_{2} \mathrm{~S} \times 9 \mathrm{H}_{2} \mathrm{O}$ was added in small increments. A stable electrode signal was achieved typically after $<60 \mathrm{~s}$. Additionally, $1 \mathrm{ml}$ of the stock solution and the final calibration solution was sampled and preserved with $100 \mu \mathrm{l}$ of $1 \mathrm{M}$ zinc acetate (ZnAc) for later colorimetric analysis (Cline 1969). $\mathrm{H}_{2} \mathrm{~S}$ concentrations were transformed to $\mathrm{TH}_{2} \mathrm{~S}$ from the measured $\mathrm{pH}$ using the equation of Jeroschewski et al. (1996) for solutions with $\mathrm{pH}<9$.

Core sectioning for solid-phase parameters and porewater solutes. Three control cores from each site were sectioned initially ( $t=0)$; at the end of the experiment, 3 control cores and 3 enriched cores from each site were sectioned. The upper $2 \mathrm{~cm}$ of cores were sectioned into $0.5 \mathrm{~cm}$ slices and the 2 to $4 \mathrm{~cm}$ depth interval was sectioned into $1 \mathrm{~cm}$ slices. Below $4 \mathrm{~cm}$ depth, 
cores were sectioned into $2 \mathrm{~cm}$ slices to 10 or $16 \mathrm{~cm}$ depth (initial and final sectioning, respectively). Individual sediment slices were homogenized before sampling according to the procedures described below, and triplicates were thus preserved during core sectionings. All visually detected macrofauna was collected and preserved in $96 \%$ ethanol for later identification. Water content, wet density, loss on ignition (LOI), and solid-phase S and Fe were determined on subsamples from each depth interval as described below. The remaining sediment was transferred to double centrifuge tubes with mounted GF/F filters and centrifuged for $10 \mathrm{~min}$ at $1500 \mathrm{rpm}($ ca. $300 \times$ g). The extracted porewater was analyzed for $\mathrm{TCO}_{2}, \mathrm{NH}_{4}{ }^{+}$, DOC, $\mathrm{Fe}^{2+}, \mathrm{SO}_{4}{ }^{2-}$, and $\mathrm{Br}^{-}$as described below.

Extraction of solid-phase reactive Fe(II) and Fe(III). Reactive solid-phase Fe(II) and Fe(III) (RFe(II) and RFe(III)) were extracted immediately after sampling, by transferring sediment subsamples ( 0.3 g) from each depth interval to preweighed centrifuge tubes containing $5 \mathrm{ml}$ of $0.5 \mathrm{M} \mathrm{HCl}$ (Lovley \& Phillips 1987). Centrifuge tubes were placed on a shaking table for exactly $30 \mathrm{~min}$. The extraction was terminated by centrifugation for $5 \mathrm{~min}$ at $3000 \mathrm{rpm}(\mathrm{ca} .1000 \times \mathrm{g}$ ) followed by GF/F filtration. RFe(II) was analyzed by the ferrozine method on untreated extract (Stookey 1970). Total reactive solid-phase Fe (TRFe) was determined on untreated extract by the ferrozine method following reduction with hydroxylamine. RFe(III) was estimated as the difference between TRFe and RFe(II). The amount of Fe bound in pyrite (pyriteFe) was calculated as described below, and total Fe (TFe) in the sediment was calculated as RFe(II) + RFe(III) + pyriteFe.

SR solid-phase $\mathbf{S}$ assay. Rates of SR were determined to $16 \mathrm{~cm}$ depth in 3 cores from each series during the final sectioning. After decanting the overlying water and before sectioning was initiated, a $2.6 \mathrm{~cm}$ i.d. subcore was taken to $6 \mathrm{~cm}$ depth with a $60 \mathrm{ml}$ cut-off syringe. Subsequently, sectioning was conducted to $6 \mathrm{~cm}$ depth. A new subcore was then taken covering the 6 to $12 \mathrm{~cm}$ depth interval followed by sectioning to $12 \mathrm{~cm}$ depth. This procedure was repeated until the sediment core was sectioned to $16 \mathrm{~cm}$ depth. Carrierfree ${ }^{35} \mathrm{~S}_{-} \mathrm{SO}_{4}{ }^{2-}$ tracer $\left(\sim 35 \mathrm{kBq} \mathrm{cm}{ }^{-3}\right.$ sediment $)$ was injected vertically into the subcores with a Hamilton syringe. Subcores were then closed with rubber stoppers and incubated for 2 to $3 \mathrm{~h}$ at $15^{\circ} \mathrm{C}$ in darkness. Incubations were terminated by slicing the subcores into the appropriate depth intervals. Sediment slices were transferred to preweighed centrifuge tubes containing $10 \mathrm{ml}$ of $0.5 \mathrm{M} \mathrm{ZnAc}$ and frozen.

SR as well as sediment pools of acid volatile sulfides (AVS) and chromium reducible sulfides (CRS) were determined using the 2-step distillation technique of Fossing \& Jørgensen (1989). Briefly, homogenized sedi- ment subsamples ( $2 \mathrm{~g}$ ) were transferred to a distillation flask and $10 \mathrm{ml}$ of $50 \%$ ethanol was added. After degassing with $\mathrm{N}_{2}$ for $10 \mathrm{~min}, 8 \mathrm{ml}$ of $6 \mathrm{M} \mathrm{HCl}$ was added to the slurry and distillation was conducted at room temperature for $30 \mathrm{~min}$ to release AVS. Finally, the slurry was distilled for 30 min while boiling after adding $16 \mathrm{ml}$ of reduced $\mathrm{Cr}^{2+}$ to release CRS. AVS and CRS released during distillations were trapped in $10 \mathrm{ml}$ of $250 \mathrm{mM}$ ZnAc. To quantify SR, the ${ }^{35} \mathrm{~S}$ activity was determined in supernatant, AVS distillate and CRS distillate on a Tri-Carb 2200 CA Liquid Scintillation Analyzer. Pools of AVS and CRS were determined by analyzing $\mathrm{TH}_{2} \mathrm{~S}$ in the distillate by the method of Cline (1969), and TRIS was calculated as AVS + CRS.

Sediment characteristics. Grain size distribution was determined by wet-sieving sediment from the upper $10 \mathrm{~cm}$ through a Wentworth mesh series (1000, 500, $250,125$, and $63 \mu \mathrm{m})$. The medium grain size was calculated from the $\varphi$ distribution of dry-weight size fractions (Inman 1952). Sediment density was estimated by determining the weight of a known volume of wet sediment using $5 \mathrm{ml}$ cut-off syringes. Sediment water content was determined as the weight loss of wet sediment after drying for $12 \mathrm{~h}$ at $105^{\circ} \mathrm{C}$ and LOI was determined as the weight loss of dry sediment after combustion for $5 \mathrm{~h}$ at $520^{\circ} \mathrm{C}$. Particulate organic carbon (POC) and total nitrogen (TN) content was determined on dried sediment subsamples, and accumulation of POC and TN was estimated as the difference between final and initial samples. LOI, POC, and TN were calculated as percent dry weight.

Sample preservation, handling, and analysis. Samples for dissolved $\mathrm{TCO}_{2}$ were preserved with saturated $\mathrm{HgCl}_{2}$ (volume ratio of 9:1) and analyzed by flow injection analysis (Hall \& Aller 1992) within 14 d of sampling. Samples for $\mathrm{SO}_{4}{ }^{2-}, \mathrm{Br}^{-}, \mathrm{NH}_{4}{ }^{+}$, and DOC were stored frozen $\left(-20^{\circ} \mathrm{C}\right)$ in precombusted $\left(5 \mathrm{~h}, 520^{\circ} \mathrm{C}\right)$ glass Exetainers ${ }^{\circledR}$ until analysis. $\mathrm{NH}_{4}{ }^{+}$was analyzed by the salicylate-hypochlorite method described by Bower \& Holm-Hansen (1980); DOC was analyzed on acidified samples using a Shimadzu TOC-5000 Total Organic Analyzer; $\mathrm{SO}_{4}{ }^{2-}$ and $\mathrm{Br}^{-}$were analyzed by liquid ion chromatography on a Dionex ICS-2000 system. Samples for $\mathrm{TH}_{2} \mathrm{~S}$ were preserved with $\mathrm{ZnAc}$ and analyzed by the method described by Cline (1969). Samples for porewater $\mathrm{Fe}^{2+}$ were acidified with $0.5 \mathrm{M} \mathrm{HCl}$ (volume ratio of 1:1), stored at room temperature, and analyzed by the ferrozine method (Stookey 1970). A variety of reduced sulfur compounds form AVS and CRS (e.g. FeS and $\mathrm{Fe}_{3} \mathrm{~S}_{4}$ in AVS and $\mathrm{FeS}_{2}$ and $\mathrm{S}^{0}$ in CRS) (Rickard \& Morse 2005), but our method does not allow for a more detailed analysis of compound speciation in reduced sulfur pools. To calculate the amount of Fe used for sulfide precipitation during the experiment (pyriteFe), it was therefore assumed that all CRS was pyrite and that 
all AVS was FeS (Canfield 1989). POC and TN were analyzed on a Carlo Erba CHN EA1108 Elemental Analyzer according to Kristensen \& Andersen (1987).

Statistical procedures. Data were analyzed by 1 -way ANOVA to test for differences between treatments (initial, final control, and final enriched cores) and for porewater solutes and solid-phase parameters in individual depth layers. ANOVA was also applied to test for treatment-specific differences between depth-integrated SR, pools of $\mathrm{RFe}(\mathrm{II}), \mathrm{RFe}(\mathrm{III}), \mathrm{TRFe}, \mathrm{AVS}, \mathrm{CRS}$, $\mathrm{POC}$, and TN, and time-integrated excess mineralization between control and enriched cores. In case of significant differences, data were subsequently ranked by Tukey's test. All statistical tests were conducted with a significance level $\alpha=0.05$.

\section{RESULTS}

\section{Visual observations}

Fe-poor cores were initially characterized by a 0.3 to $0.5 \mathrm{~cm}$ pale brown oxidized layer overlying a pale grey sediment layer with scattered darker patches. Shells and larger particles were evident from $>10 \mathrm{~cm}$ depth. Fe-rich cores were characterized by a brown oxidized surface layer $\sim 0.5 \mathrm{~cm}$ thick and easily distinguished from the reduced anoxic sediment, which was dark grey with intermingled blackish patches. Macrofauna burrows were evident to $12 \mathrm{~cm}$ depth in both sediment types and the burrow walls were light brown, indicating the presence of oxidized iron.

Both types of sediment responded rapidly to surface addition of labile OM. The oxidized surface layer was rapidly diminished to a $<1 \mathrm{~mm}$ thick film in Fe-poor sediment, but remained at least $1 \mathrm{~mm}$ thick in Fe-rich cores. Small patches of white Beggiatoa spp.-like bacteria appeared on the sediment surface within 2 to $3 \mathrm{~d}$ after the first enrichment. These patches continued to develop into mats covering $>80 \%$ of the surface after 11 and $25 \mathrm{~d}$ in Fe-poor and Fe-rich cores, respectively. Subsequently, the mats varied in size with the highest degree of coverage in days following the enrichments. The upper 1 to $2 \mathrm{~cm}$ of the sediment gradually turned blackish grey in Fe-poor cores and black in enriched Fe-rich cores throughout the experiment. The enriched sediments appeared unaffected by the organic additions below $2 \mathrm{~cm}$ depth. Macrofauna persisted within the enriched cores despite the repeated input of OM to the sediment surface. This was evidenced by the presence of burrows with oxidized burrow walls and occasional sightings of infauna along the core perimeter.

\section{Sediment characteristics}

The sediment at the Fe-poor site consisted of medium sand with a mean grain size of $474 \mu \mathrm{m}$ and a silt-clay fraction of $<1 \%$, while the sediment at the Fe-rich site was composed of fine sand with a mean grain size of $229 \mu \mathrm{m}$ and a silt-clay fraction of $4 \%$. Both sediments were similar with respect to density and TN content, but porosity, POC content, and RFe content were higher in Fe-rich sediment (Table 1).

In Fe-poor cores, LOI decreased from $1.3 \pm 0.2$ (SE) \% at the surface to $0.5 \pm 0.01 \%$ at $0.75 \mathrm{~cm}$ depth before organic addition. Below $1 \mathrm{~cm}$ depth, LOI was low, at an average concentration of $0.37 \pm 0.02 \%$. POC and TN content were initially $0.56 \pm 0.09 \%$ and $0.08 \pm 0.01 \%$, respectively, at $0.25 \mathrm{~cm}$ depth, and an average of $0.17 \pm$ $0.01 \%$ and $0.02 \pm 0.01 \%$ below. LOI, POC, and TN were not affected significantly by enrichment at any depth in Fe-poor cores. In Fe-rich cores, LOI initially decreased gradually from $1.7 \pm 0.1 \%$ at the surface to $1.3 \pm 0.1 \%$ at $5 \mathrm{~cm}$ depth. Below $5 \mathrm{~cm}$, LOI asymptotically approached $1.1 \%$. In the final sectioning, LOI had not changed in control cores, but in enriched cores LOI was significantly $(p=0.011)$ higher in the upper $1.5 \mathrm{~cm}$, with average values of $2.3 \pm 0.5 \%$. Similarly, POC and TN content increased significantly to $1.2 \pm 0.2 \%(\mathrm{p}=0.026)$ and $0.19 \pm$ $0.03 \%(p=0.025)$ in the upper $0.5 \mathrm{~cm}$ compared with $0.51 \pm 0.03 \%$ and $0.07 \pm 0.01 \%$ initially for POC and TN.

\section{Macrofauna, bioirrigation intensity, and porewater solutes}

Fauna in Fe-poor sediment was dominated by the polychaetes Marenzellaria viridis, Nereis spp., Heteromastus filiformis, and Nephtys spp., and the oligochaete Tubificoides benedii. Initially, worms were present at a total density of $796 \pm 115$ (SE) $\mathrm{m}^{-2}$. Worm density increased to $1790 \pm 300 \mathrm{~m}^{-2}$ in final enriched cores, with dominance of $M$. viridis, $H$. filiformis, and $T$. benedii, while worm density decreased to $596 \pm$ $114 \mathrm{~m}^{-2}$ in final control cores, where $M$. viridis had disappeared. The same pattern was observed in Fe-rich

Table 1. Initial sediment characteristics in Fe-poor and Fe-rich sediment. Mean \pm SD density, porosity, particulate organic carbon (POC) content, and total nitrogen (TN) content were determined on homogenized sediment samples from 0 to $10 \mathrm{~cm}$ depth $(\mathrm{n}=3)$. Reactive Fe (RFe) content was the average depth-integrated content in initial cores to $10 \mathrm{~cm}$ depth $(\mathrm{n}=3)$

\begin{tabular}{|lccccr|}
\hline Sediment & $\begin{array}{c}\text { Density } \\
\left(\mathrm{g} \mathrm{cm}^{-3}\right)\end{array}$ & Porosity & $\begin{array}{c}\text { POC } \\
(\% \text { dry wt })\end{array}$ & $\begin{array}{c}\text { TN } \\
(\% \text { dry wt })\end{array}$ & $\begin{array}{c}\text { RFe } \\
\left(\mu \mathrm{mol} \mathrm{cm}^{-3}\right)\end{array}$ \\
\hline Fe-poor & $1.93 \pm 0.02$ & $0.42 \pm 0.005$ & $0.18 \pm 0.01$ & $0.04 \pm 0.038$ & $3.1 \pm 0.6$ \\
Fe-rich & $1.95 \pm 0.03$ & $0.55 \pm 0.001$ & $0.41 \pm 0.02$ & $0.04 \pm 0.003$ & $106.0 \pm 19.8$ \\
\hline
\end{tabular}


sediment, where infauna was dominated by juvenile ( 2 to $3 \mathrm{~mm}$ ) individuals of the bivalves Corbula gibba and Abra alba and the polychaetes M. viridis, Nereis spp., Eteone longa, Scoloplos armiger, and Polydora spp. as well as $T$. benedii. Worms and juvenile bivalves were initially present at high densities (1194 \pm 199 and 1326 $\pm 239 \mathrm{~m}^{-2}$, respectively). Similar densities were found in final enriched cores $\left(1393 \pm 459\right.$ and $1127 \pm 470 \mathrm{~m}^{-2}$, respectively), while much lower densities of bivalves $\left(265 \pm 153 \mathrm{~m}^{-2}\right)$ and worms $\left(597 \pm 304 \mathrm{~m}^{-2}\right)$ were found in final controls. Juvenile bivalves were always positioned in the upper $1 \mathrm{~cm}$ of the sediment, where they survived despite high $\mathrm{TH}_{2} \mathrm{~S}$ concentrations.

Bioirrigation estimated from $\mathrm{Br}^{-}$incubations was significant in all treatments and generally more pronounced in enriched than control cores (Fig. 1). Average bioirrigation intensity in Fe-poor controls was $13.7 \pm 8.6(\mathrm{SE})$ compared to $36.1 \pm 10.0 \mathrm{l} \mathrm{m}^{-2} \mathrm{~d}^{-1}$ in enriched cores. The same pattern was observed in Ferich treatments, where bioirrigation intensity was $5.0 \pm$ 1.1 and $12.6 \pm 5.5 \mathrm{l} \mathrm{m}^{-2} \mathrm{~d}^{-1}$ in control and enriched cores, respectively. Bioirrigation was significantly correlated to worm density, except for a single outlier populated entirely by Tubificoides benedii and Scoloplos armiger (Fig. 2).

Total dissolved carbon (TDC $\sim \mathrm{TCO}_{2}+\mathrm{DOC}$ ) was initially constant with depth at 4 to $4.6 \mathrm{mM}$ in both types of sediment and did not change in final Fe-poor controls. In final Fe-rich controls, TDC accumulated to $8.0 \pm$
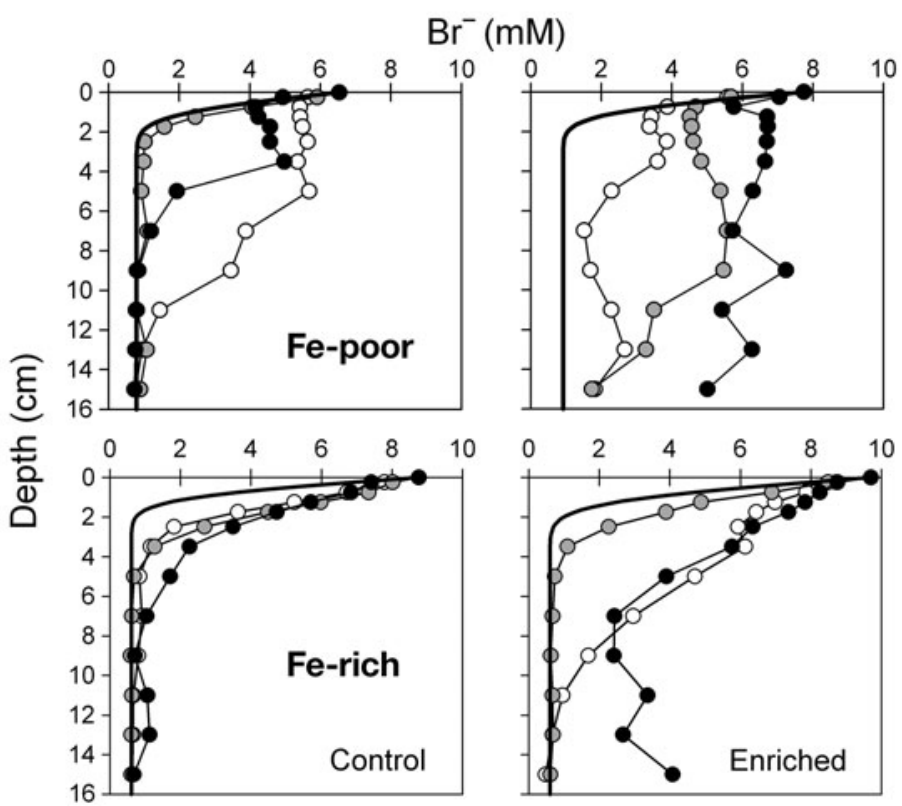

Fig. 1. $\mathrm{Br}^{-}$concentration in porewater determined after the final sectioning in Fe-poor (upper panels) and Fe-rich (lower panels) sediment. Left and right panels indicate control and enriched sediment, respectively. Solid lines represent the theoretical $\mathrm{Br}^{-}$concentration resulting from passive diffusion. Individual profiles represent 1 sediment core

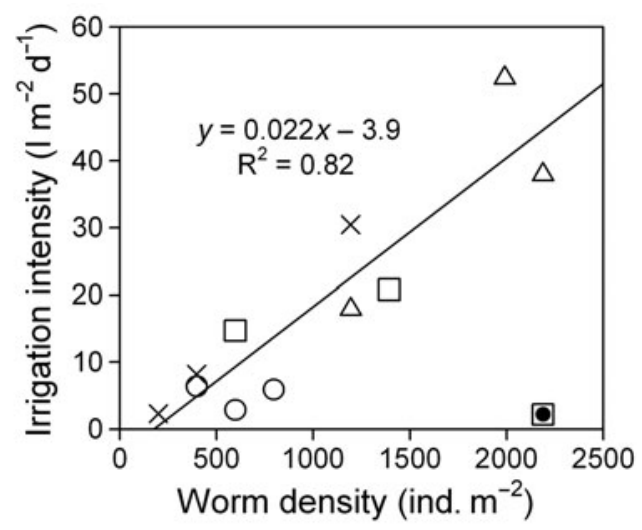

Fig. 2. Irrigation intensity vs. worm density in Fe-poor control $(X)$ and enriched $(\Delta)$ cores and Fe-rich control $(O)$ and enriched $(\square)$ cores. Data marked with $\bullet$ were excluded from the linear regression

0.6 (SE) $\mathrm{mM}$ below $3 \mathrm{~cm}$ depth $(\mathrm{p}=0.009)$. TDC accumulated significantly in the upper part of enriched cores, reaching $13.5 \pm 2.8 \mathrm{mM}(\mathrm{p}=0.031)$ in the upper $0.5 \mathrm{~cm}$ of Fe-poor and $21 \pm 5.3 \mathrm{mM}(\mathrm{p}=0.004)$ in the upper $0.5 \mathrm{~cm}$ of $\mathrm{Fe}$-rich sediment (Fig. 3). $\mathrm{NH}_{4}{ }^{+}$was initially constant with depth at $133 \pm 14$ and $233 \pm$ $10 \mu \mathrm{M}$ in Fe-poor and Fe-rich sediment, respectively, and accumulated only below 1 and $3 \mathrm{~cm}$ to average concentrations of $517 \pm 220$ and $516 \pm 100 \mu \mathrm{M}$ in final controls. $\mathrm{NH}_{4}{ }^{+}$in final enriched cores was higher than the parallel control cores, but the difference was only significant in the upper 0.5 and $2 \mathrm{~cm}$ of Fe-poor $(\mathrm{p}=$ $0.01)$ and Fe-rich $(\mathrm{p}=0.031)$ sediment, respectively, where $\mathrm{NH}_{4}{ }^{+}$was $1268 \pm 430$ and $567 \pm 222 \mu \mathrm{M}$ (Fig. 3). The 2 types of sediment differed with respect to dissolved $\mathrm{Fe}^{2+}$. In $\mathrm{Fe}$-poor sediment, no $\mathrm{Fe}^{2+}$ was detected in either initial or final controls and was only detected in the upper $1.5 \mathrm{~cm}$ of enriched cores (maximum of $52 \pm$ $6 \mu \mathrm{M}$ at 0 to $0.5 \mathrm{~cm}$ depth). In Fe-rich sediment, $\mathrm{Fe}^{2+}$ was initially present at low levels $(<25 \mu \mathrm{M})$ in the upper $4 \mathrm{~cm}$, but increased significantly in both final control and enriched cores. In final Fe-rich controls, a subsurface $\mathrm{Fe}^{2+}$ peak of $353 \pm 206 \mu \mathrm{M}$ was evident at $2.5 \mathrm{~cm}$ depth, and $\mathrm{Fe}^{2+}$ decreased gradually to reach $<35 \mu \mathrm{M}$ at the sediment surface and at $5 \mathrm{~cm}$ depth. In enriched Fe-rich sediment, $\mathrm{Fe}^{2+}$ was high (average concentration $356 \pm 97 \mu \mathrm{M}$ ) in the upper $1.5 \mathrm{~cm}$ and decreased gradually below to reach $5 \mu \mathrm{M}$ at $5 \mathrm{~cm}$ depth. Organic enrichment had little effect on porewater $\mathrm{SO}_{4}{ }^{2-}$ in both types of sediment, with concentrations close to that of overlying water at all depths ( 15 mM) (Fig. 3).

\section{Microprofiles of $\mathrm{pH}, \mathrm{O}_{2}$, and $\mathrm{TH}_{2} \mathrm{~S}$}

In $\mathrm{Fe}$-poor control cores, $\mathrm{O}_{2}$ penetration increased significantly from $1.29 \pm 0.07$ to $1.97 \pm 0.12 \mathrm{~mm}$ during 


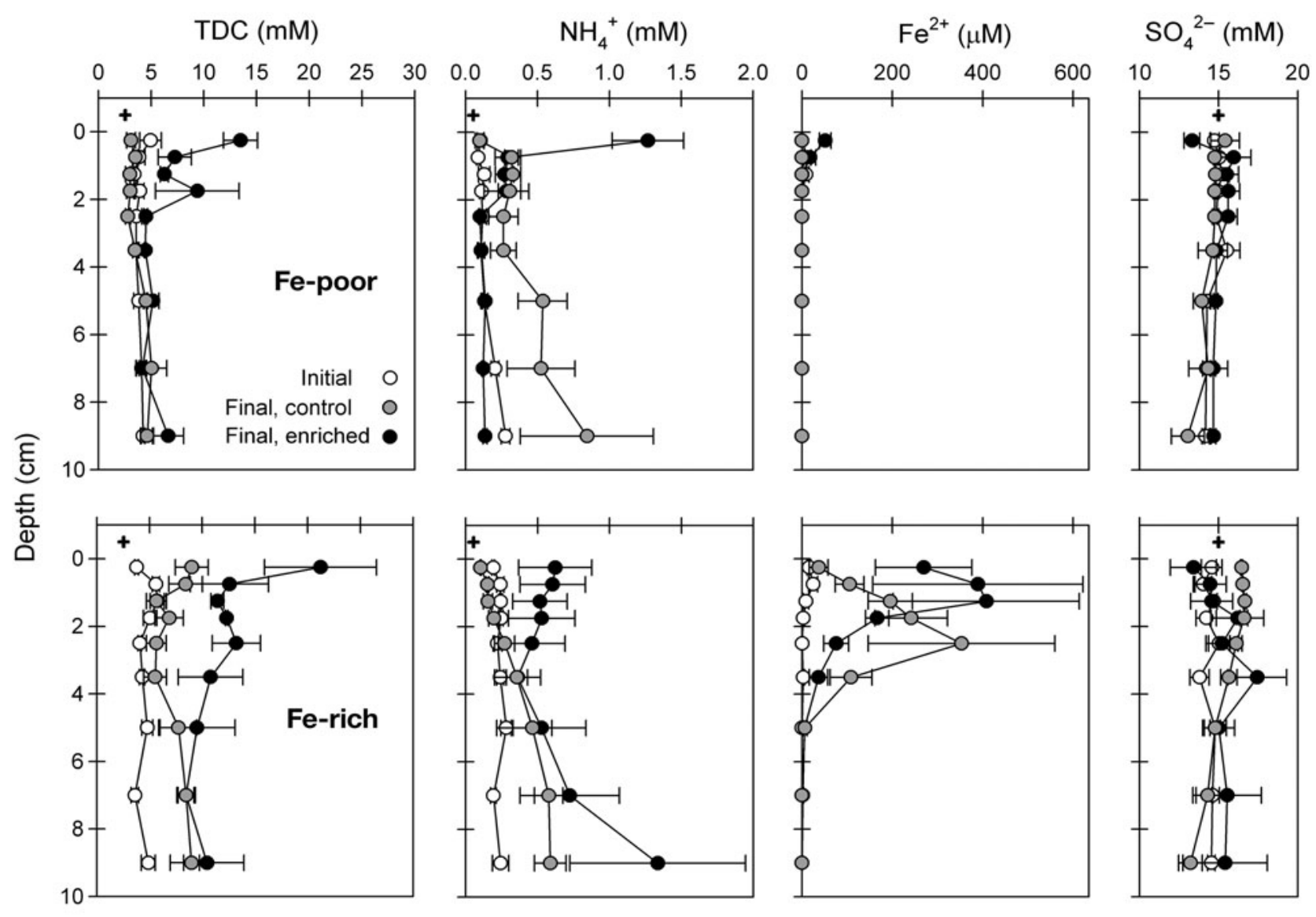

Fig. 3. Porewater profiles of total dissolved carbon (TDC), $\mathrm{NH}_{4}{ }^{+}, \mathrm{Fe}^{2+}$, and $\mathrm{SO}_{4}{ }^{2-}$ in Fe-poor (upper panels) and Fe-rich (lower panels) sediment. $(\circ)$ and $(\circ)$ represent initial and final controls and $(\bullet)$ represents enriched cores. Crosses (+) indicate the solute concentration in the overlying water. No $\mathrm{Fe}^{2+}$ was measured in the overlying water, and no $\mathrm{Fe}^{2+}$ was detected in the porewater of Fe-poor controls. Error bars represent SE $(n=3)$

the experiment $(\mathrm{p}<0.001) . \mathrm{O}_{2}$ penetration in Fe-rich controls was $2 \mathrm{~mm}$ throughout the experiment. Organic enrichment diminished $\mathrm{O}_{2}$ penetration depth to zero in patches covered with Beggiatoa spp. and to no more than $\sim 0.9 \mathrm{~mm}$ in non-covered patches of both types of sediment (Fig. 4).

The low levels of $\mathrm{TH}_{2} \mathrm{~S}$ that were detected initially from 3 to $20 \mathrm{~mm}$ depth (up to $330 \mu \mathrm{M}$ ) in Fe-poor control cores disappeared by the end of the experiment. $\mathrm{TH}_{2} \mathrm{~S}$ was always absent in the top $2 \mathrm{~cm}$ of Fe-rich control cores. All enriched cores rapidly developed a characteristic subsurface peak of $\mathrm{TH}_{2} \mathrm{~S}$ in the upper $2 \mathrm{~cm}$ following the initial enrichment (Fig. 4). The shape of all $\mathrm{TH}_{2} \mathrm{~S}$ profiles was similar to that depicted in Fig. 4 throughout the experiment. Peak concentration in enriched Fe-poor sediment increased from $0.28 \pm 0.13$ (SE) $\mathrm{mM}$ around Day 20 to an average of $0.89 \pm 0.22 \mathrm{mM}$ during the remainder of the experiment (Fig. 5). In enriched Fe-rich cores, the $\mathrm{TH}_{2} \mathrm{~S}$ peak rose from $0.55 \pm 0.10 \mathrm{mM}$ from Day 10 and was on average $0.65 \pm 0.13 \mathrm{mM}$ during the rest of the experiment. The peak of $\mathrm{TH}_{2} \mathrm{~S}$ was always accompanied by a drop in $\mathrm{pH}$ from 7.6 at the sediment- water interface to a minimum of 6.8 to 7.2 within the upper $2 \mathrm{~cm}$ of the sediment, and the lowest $\mathrm{pH}$ was measured in Fe-poor sediment (Fig. 4).

\section{SR rates}

There was a decreasing trend in SR with depth in Fepoor control cores, ranging from $205 \pm 21$ (SE) nmol $\mathrm{cm}^{-3} \mathrm{~d}^{-1}$ in the upper $2 \mathrm{~cm}$ to about $50 \pm 11 \mathrm{nmol} \mathrm{cm}^{-3}$ $\mathrm{d}^{-1}$ below $8 \mathrm{~cm}$ depth (Fig. 6). SR in Fe-rich control cores did not vary with depth and was on average $164 \pm 17 \mathrm{nmol} \mathrm{cm}^{-3} \mathrm{~d}^{-1}$. SR was highly elevated in the upper $1 \mathrm{~cm}$ of enriched cores, reaching $1280 \pm$ $128 \mathrm{nmol} \mathrm{cm}^{-3} \mathrm{~d}^{-1}$ in Fe-poor and $1912 \pm 200 \mathrm{nmol} \mathrm{cm}^{-3}$ $\mathrm{d}^{-1}$ in Fe-rich sediment. Depth-integrated SR in enriched Fe-poor cores was $31.5 \pm 3.1 \mathrm{mmol} \mathrm{m}^{-2} \mathrm{~d}^{-1}$, which was twice that measured in control cores (16.4 \pm $3.2 \mathrm{mmol} \mathrm{m}^{-2} \mathrm{~d}^{-1}, \mathrm{p}=0.028$ ). Depth-integrated SR to $16 \mathrm{~cm}$ depth showed no significant difference between control and enriched Fe-rich cores $(27.6 \pm 1.9$ and $36.3 \pm 5.6 \mathrm{mmol} \mathrm{m}^{-2} \mathrm{~d}^{-1}$, respectively). 


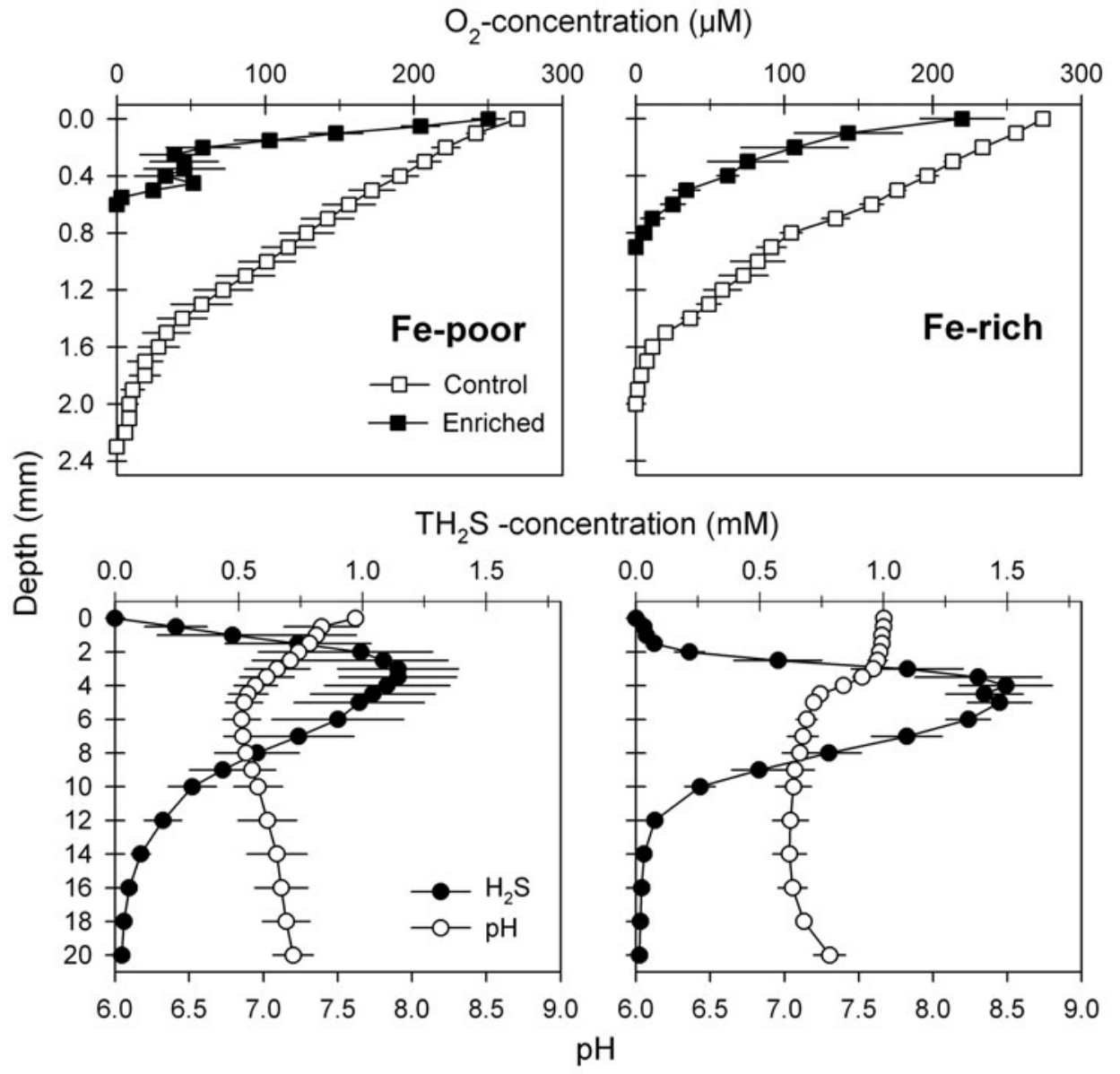

Fig. 4. $\mathrm{O}_{2}, \mathrm{pH}$, and total dissolved sulfide $\left(\mathrm{TH}_{2} \mathrm{~S}\right)$ profiles measured in single Fe-poor sediment (left panels) and Fe-rich sediment (right panels) cores. Profiles from Fe-poor and Ferich sediment were measured on Days 59 and 35 of the experiment, respectively. $\mathrm{O}_{2}$ profiles from enriched cores were measured outside Beggiatoa spp. mats. $\mathrm{TH}_{2} \mathrm{~S}$ and $\mathrm{pH}$ in lower panels are only shown for enriched cores. Error bars represent inter-core variability based on 4 or $5 \mathrm{O}_{2}, 3 \mathrm{TH}_{2} \mathrm{~S}$, and $3 \mathrm{pH}$ profiles

\section{Solute fluxes}

In Fe-poor controls, SOU and effluxes of $\mathrm{TCO}_{2}$ were stable at an average of $31.1 \pm 2.4(\mathrm{SE})$ and $33.1 \pm$ $1.5 \mathrm{mmol} \mathrm{m}^{-2} \mathrm{~d}^{-1}$, respectively, (Table 2) and $\mathrm{NH}_{4}^{+}$ effluxes decreased gradually from $6.6 \pm 1.2 \mathrm{mmol} \mathrm{m}^{-2}$ $\mathrm{d}^{-1}$ initially to $1.9 \pm 0.8 \mathrm{mmol} \mathrm{m}^{-2} \mathrm{~d}^{-1}$ by the end
(Fig. 7). SOU and effluxes of $\mathrm{TCO}_{2}$ in Fe-rich controls were low and constant at $25.5 \pm 0.5$ and $27.3 \pm \mathrm{mmol}$ $\mathrm{m}^{-2} \mathrm{~d}^{-1}$ (Table 2), respectively, whereas $\mathrm{NH}_{4}{ }^{+}$effluxes decreased from initial release of $4 \pm 0.5 \mathrm{mmol} \mathrm{m}^{-2} \mathrm{~d}^{-1}$ to $\mathrm{NH}_{4}{ }^{+}$uptake of $-2 \pm 0.5 \mathrm{mmol} \mathrm{m}^{-2} \mathrm{~d}^{-1}$ on Days 21 to 36. After Day 36, $\mathrm{NH}_{4}{ }^{+}$fluxes gradually stabilized at $\sim 0.8 \mathrm{mmol} \mathrm{m}^{-2} \mathrm{~d}^{-1}$.
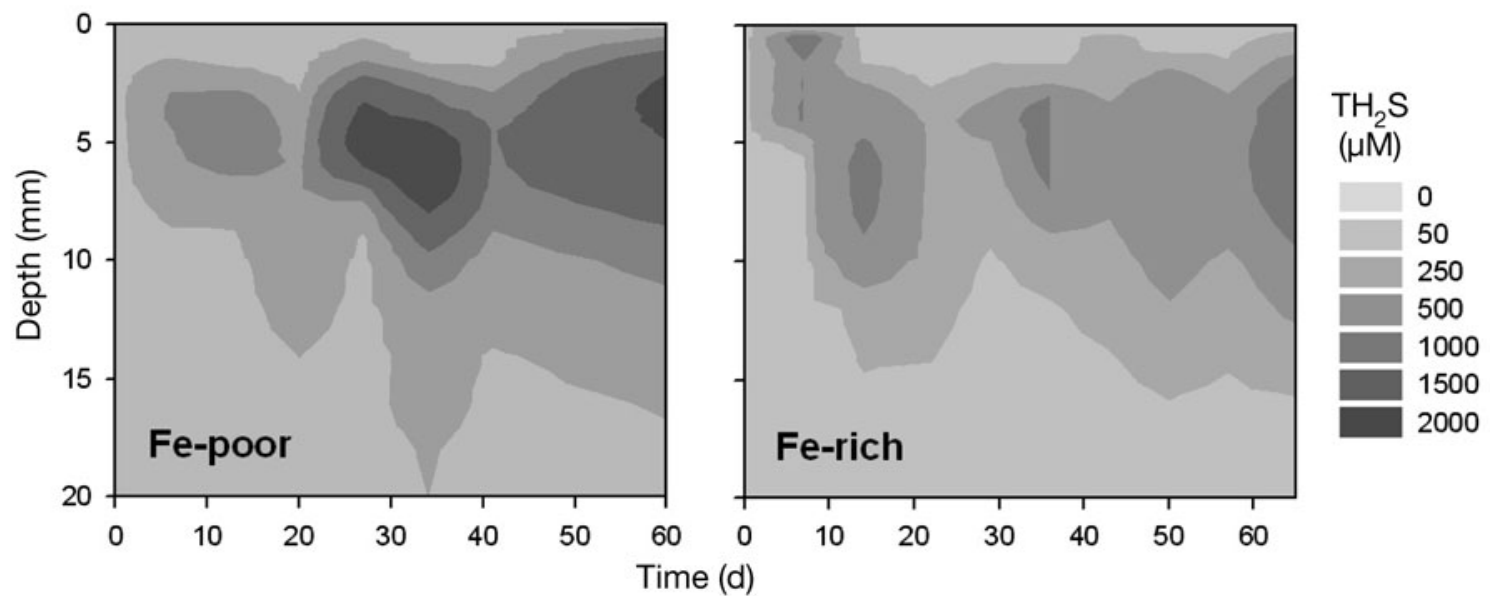

Fig. 5. Temporal and spatial development of total dissolved sulfide $\left(\mathrm{TH}_{2} \mathrm{~S}\right.$ ) in Fe-poor (left panel) and Fe-rich (right panel) enriched sediment obtained from $\mathrm{TH}_{2} \mathrm{~S}$ microprofiles 
Fig. 6. Sulfate reduction rates (SRR) in final enriched cores and controls in Fe-poor (left panel) and Fe-rich (right panel) sediments. Open and filled circles indicate control and enriched sediment, respectively. Error bars indicate SE $(n=3)$

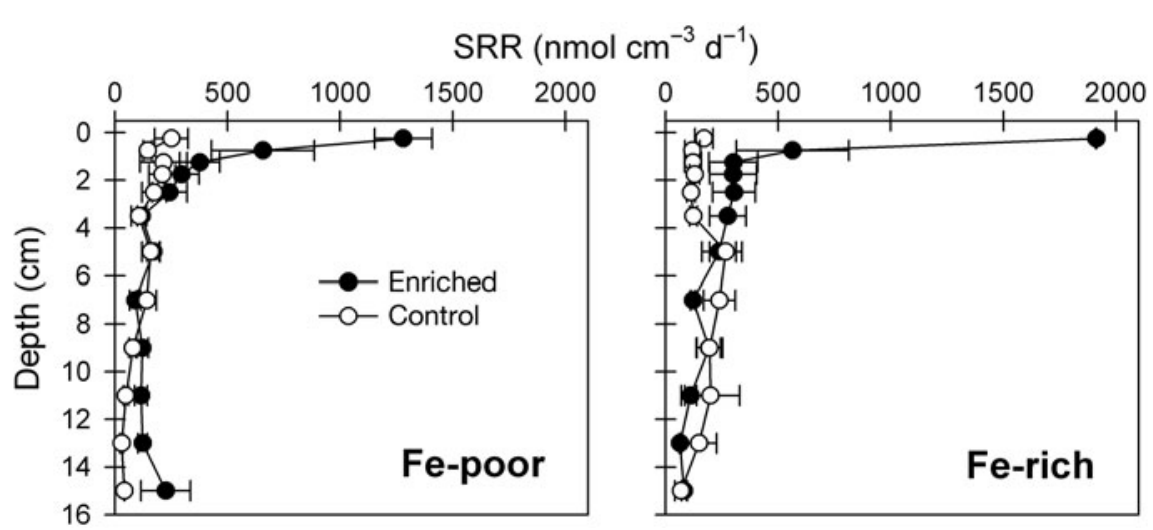

Organic enrichments led to significant increases in SOU, $\mathrm{TCO}_{2}$ efflux, and $\mathrm{NH}_{4}{ }^{+}$efflux. After an initial lag phase of $\sim 10 \mathrm{~d}$ for both sediment types, fluxes showed an oscillatory pattern in which highest fluxes followed enrichments (Fig. 7). SOU and $\mathrm{TCO}_{2}$ and $\mathrm{NH}_{4}{ }^{+}$effluxes in enriched Fe-poor cores were on average 4,5, and 6 times higher, respectively, compared to control values. SOU and $\mathrm{TCO}_{2}$ and $\mathrm{NH}_{4}{ }^{+}$ effluxes fluctuated more in enriched Fe-rich than in Fe-poor sediment and were on average 5 times higher than controls. $\mathrm{TCO}_{2}$ release in particular appeared to follow an oscillatory pattern (Fig. 7). High effluxes of up to $370 \mathrm{mmol} \mathrm{m}^{-2} \mathrm{~d}^{-1}$ occurred immediately after enrichments followed by a rapid attenuation until the next enrichment. The pattern of $\mathrm{NH}_{4}{ }^{+}$release was similar to $\mathrm{TCO}_{2}$ release and despite different patterns in the 2 types of sediment, average $\mathrm{NH}_{4}{ }^{+}$effluxes were similar (Table 2).

\section{$\mathrm{C}$ and $\mathbf{N}$ budgets}

Time-integrated excess mineralization due to enrichment was calculated as the flux enhancement in enriched cores relative to controls. In Fe-poor cores, $34 \pm 1$ (SE) and $40 \pm 2 \%$ of added POC and TN respectively was mineralized and released as $\mathrm{TCO}_{2}$ and $\mathrm{NH}_{4}{ }^{+}$during the experiment, which was lower than for Fe-rich sediment, where $\mathrm{TCO}_{2}$ and $\mathrm{NH}_{4}{ }^{+}$release accounted for $56 \pm 4$ and $47 \pm 5 \%$ of added POC and TN, respectively (Table 3). Accumulation of dissolved $\mathrm{C}$ and $\mathrm{N}$ in sediment porewaters was low in both types of sediment and contributed insignificantly to the budget. In Fe-poor sediment, accumulation of POC and TN suggested almost complete mineralization of added OM since only 9 $\pm 2 \%$ of added POC and no TN accumulated by the end. Accumulation was higher in Fe-rich sediment, attaining $22 \pm 6 \%$ of added OM. Thus, the apparent daily

Table 2. Sediment oxygen uptake (SOU) and effluxes of total $\mathrm{CO}_{2}\left(\mathrm{TCO}_{2}\right)$ and $\mathrm{NH}_{4}{ }^{+}$measured in Fe-poor and Fe-rich sediment over 9 wk of incubation (average $\pm \mathrm{SE}$ ). $n$ : number of incubations

\begin{tabular}{|lcccccc|}
\hline \multirow{2}{*}{ Sediment } & \multicolumn{2}{c}{$\mathrm{TCO}_{2}\left(\mathrm{mmol} \mathrm{m}^{-2} \mathrm{~d}^{-1}\right)$} & \multicolumn{2}{c|}{$\mathrm{SOU}\left(\mathrm{mmol} \mathrm{m}^{-2} \mathrm{~d}^{-1}\right)$} & \multicolumn{2}{c}{$\mathrm{NH}_{4}^{+}\left(\mathrm{mmol} \mathrm{m}^{-2} \mathrm{~d}^{-1}\right)$} \\
& Control & Enriched & Control & Enriched & Control & Enriched \\
\hline Fe-poor & $31.1 \pm 2.4(\mathrm{n}=36)$ & $159.7 \pm 7.2(\mathrm{n}=46)$ & $33.1 \pm 1.5(\mathrm{n}=33)$ & $135.3 \pm 4.7(\mathrm{n}=45)$ & $3.2 \pm 0.4(\mathrm{n}=36)$ & $23.3 \pm 1.3(\mathrm{n}=46)$ \\
Fe-rich & $27.3 \pm 1.8(\mathrm{n}=39)$ & $221.0 \pm 13.0(\mathrm{n}=53)$ & $25.5 \pm 0.5(\mathrm{n}=41)$ & $126.7 \pm 4.8(\mathrm{n}=51)$ & $0.4 \pm 0.3(\mathrm{n}=44)$ & $23.9 \pm 1.8(\mathrm{n}=53)$ \\
\hline
\end{tabular}

Table 3. Mineralized, lost, and accumulated $\mathrm{C}$ and $\mathrm{N}$ and relative (in parentheses) to total added $\mathrm{C}\left(21.4 \mathrm{~mol} \mathrm{~m}^{-2}\right)$ and $\mathrm{N}\left(3.02 \mathrm{~mol} \mathrm{~m}^{-2}\right)$. Total $\mathrm{CO}_{2}\left(\mathrm{TCO}_{2}\right)$ and $\mathrm{NH}_{4}{ }^{+}$release was calculated as time-integrated excess flux in enriched cores relative to control cores. Accumulated particulate organic carbon (POC) and total nitrogen (TN) were calculated as the difference in the upper $2 \mathrm{~cm}$ of final enriched cores and initial controls. Accumulated total dissolved carbon (TDC) and $\mathrm{NH}_{4}{ }^{+}$were obtained from depth integration of porewater profiles to $10 \mathrm{~cm}$ depth. Error values indicate SE $(n=3)$. PON: particulate organic nitrogen

\begin{tabular}{|lrrr|}
\hline $\begin{array}{c}\mathrm{C} \text { or } \mathrm{N} \text { in Fe-poor } \\
\text { or -rich sediment }\end{array}$ & $\begin{array}{c}\mathrm{TCO}_{2} \text { or } \mathrm{NH}_{4}{ }^{+} \text {release } \\
\left(\mathrm{mmol} \mathrm{m}^{-2}\right)\end{array}$ & $\begin{array}{c}\text { Accumulated POC or PON } \\
\left(\mathrm{mmol} \mathrm{m}^{-2}\right)\end{array}$ & $\begin{array}{c}\text { Accumulated TDC or NH }_{4}{ }^{+} \\
\left(\mathrm{mmol} \mathrm{m}^{-2}\right)\end{array}$ \\
\hline $\mathrm{C}$ in Fe-poor & $7.36 \pm 0.23(34 \%)$ & $1.79 \pm 0.29(8.4 \%)$ & $0.09 \pm 0.04(0.4 \%)$ \\
$\mathrm{C}$ in Fe-rich & $11.92 \pm 0.96(56 \%)$ & $4.57 \pm 1.26(21 \%)$ & $0.21 \pm 0.11(1.0 \%)$ \\
$\mathrm{N}$ in Fe-poor & $1.21 \pm 0.07(40 \%)$ & $-0.03 \pm 0.1(-)$ & $2.5 \times 10^{-3} \pm 1.4 \times 10^{-3}(0.1 \%)$ \\
$\mathrm{N}$ in Fe-rich & $1.43 \pm 0.15(47 \%)$ & $0.68 \pm 0.26(22 \%)$ & $1.5 \times 10^{-2} \pm 1.1 \times 10^{-3}(0.5 \%)$ \\
\hline
\end{tabular}




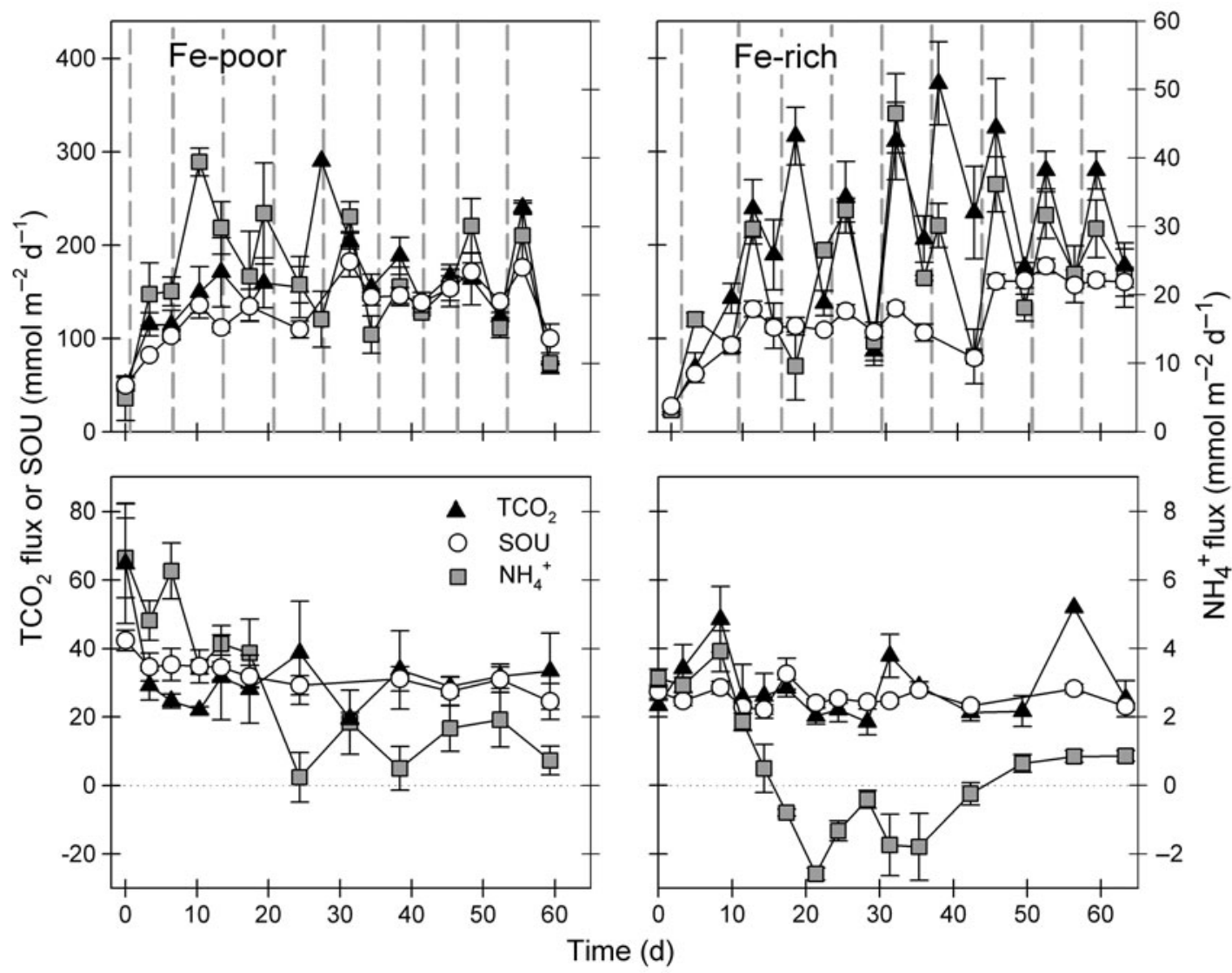

Fig. 7. Sediment oxygen uptake (SOU) and effluxes of total $\mathrm{CO}_{2}\left(\mathrm{TCO}_{2}\right)$ and $\mathrm{NH}_{4}{ }^{+}$in Fe-poor (left panels) and Fe-rich (right panels) sediment. Upper panels indicate enriched cores and lower panels indicate controls. Dashed vertical lines in upper panels indicate times of enrichment. Dotted horizontal lines in lower panels indicate zero. Error bars indicate $\mathrm{SE}(\mathrm{n}=3)$

$\mathrm{C}$ and $\mathrm{N}$ mineralization was 310 and $49 \mathrm{mmol} \mathrm{m} \mathrm{m}^{-2}$ respectively in Fe-poor sediment and 244 and $34.9 \mathrm{mmol}$ $\mathrm{m}^{-2} \mathrm{~d}^{-1}$ respectively in Fe-rich sediment.

\section{Behavior of particulate Fe and $S$}

TRIS was low in initial and final Fe-poor controls, exhibiting stable levels of $5.4 \pm 0.7$ (SE) and $4.1 \pm$ $0.8 \mu \mathrm{mol} \mathrm{cm}{ }^{-3}$, respectively, except for a peak of $23.2 \pm$ $1.6 \mu \mathrm{mol} \mathrm{cm}{ }^{-3}$ in the upper $0.5 \mathrm{~cm}$ of initial sediment (Fig. 8). Less than 10 and $27 \%$, respectively, of TRIS was AVS. TRIS was higher in the upper $2 \mathrm{~cm}$ of Fepoor enriched cores, showing an average of $15.8 \pm$ $2.4 \mu \mathrm{mol} \mathrm{cm} \mathrm{cm}^{-3}$ (Fig. 8), and the importance of AVS was $<6 \%$. Depth-integrated TRIS pools to $4 \mathrm{~cm}$ depth was almost doubled when compared to initial controls (Table 4), but the increase was not significant due to high inter-core variability. Initial Fe-rich controls showed a gradual increase in TRIS from $29.8 \pm$ $0.7 \mu \mathrm{mol} \mathrm{cm} \mathrm{cm}^{-3}$ at 0 to $0.5 \mathrm{~cm}$ depth to $53.2 \pm 3.5 \mu \mathrm{mol}$ $\mathrm{cm}^{-3}$ below $4 \mathrm{~cm}$ depth (Fig. 8). AVS contribution in- creased from $<10 \%$ of TRIS in the surface layer to $42 \%$ at $2.5 \mathrm{~cm}$ depth and 23 to $30 \%$ below. TRIS pools were lower in final Fe-rich controls, and increased from $9.7 \pm$

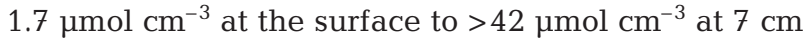
depth and below. The lowered TRIS was entirely due to loss of CRS since AVS was similar to or higher than initial levels. Thus, AVS constituted up to $70 \%$ of TRIS in final Fe-rich controls. Depth-integrated pools showed a significant TRIS increase in Fe-rich enriched cores ( $p=0.009$, Table 4 ) primarily due to a 3 -fold increase in the surface layer (up to $108 \mu \mathrm{mol} \mathrm{cm} \mathrm{cm}^{-3}$ ).

Initial Fe-poor controls showed a distinct surface

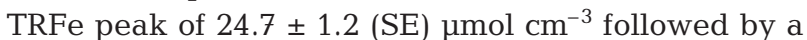
rapid decrease to $4-8 \mu \mathrm{mol} \mathrm{\textrm {cm } ^ { - 3 }}$ below (Fig. 9). RFe(III) was only measurable in the upper $0.5 \mathrm{~cm}$ $\left(5.9 \pm 0.3 \mu \mathrm{mol} \mathrm{cm}{ }^{-3}\right)$. RFe(II) and pyriteFe contributed equally to TRFe below $0.5 \mathrm{~cm}$. Final Fe-poor controls showed a similar pattern except for an increase in $\mathrm{RFe}$ (III) to $13 \pm 6 \mu \mathrm{mol} \mathrm{cm}{ }^{-3}$ in the upper $0.5 \mathrm{~cm}$ and slightly lower levels of pyriteFe. Enriched Fe-poor cores were also similar to initial controls, except for diminished levels of RFe(III) to $<0.5 \mu \mathrm{mol} \mathrm{cm} \mathrm{cm}^{-3}$. TRFe 
Table 4. Changes in depth-integrated $(0$ to $4 \mathrm{~cm})$ pools of reactive iron and sulfide species in initial sediment and the change $(\Delta \mathrm{Fe}$ or $\Delta \mathrm{S})$ observed in the final control and enriched Fe-poor and Fe-rich sediment. Positive and negative values indicate an increase or reduction in pool size, respectively. *Significant differences between 'Initial' and 'Final, control' or 'Final, enriched' cores (1-way ANOVA, $\mathrm{p}<0.05)$. Error values indicate SE $(n=3)$. AVS: acid volatile sulfides; CRS: chromium reducible sulfides; RFe(II): reactive Fe(II); RFe(III): reactive Fe(III); TRFe: total reactive Fe

\begin{tabular}{|c|c|c|c|c|c|c|c|c|c|c|}
\hline & \multicolumn{5}{|c|}{ Fe-poor sediment } & \multicolumn{5}{|c|}{-Fe-rich sediment } \\
\hline & TRFe & $\mathrm{RFe}(\mathrm{II})$ & RFe(III) & AVS & CRS & TRFe & $\mathrm{RFe}(\mathrm{II})$ & RFe(III) & AVS & CRS \\
\hline $\begin{array}{l}\text { Initial } \\
\left(\mathrm{mmol} \mathrm{m}^{-2}\right)\end{array}$ & $361 \pm 27$ & $148 \pm 15$ & $39.2 \pm 3.2$ & $15.4 \pm 2.8$ & $359 \pm 43$ & $4417 \pm 79$ & $3630 \pm 89$ & $250 \pm 62$ & $427 \pm 89$ & $1152 \pm 89$ \\
\hline $\begin{array}{l}\text { Final, control } \\
(\Delta \mathrm{Fe} \text { or } \Delta \mathrm{S}) \\
\left(\mathrm{mmol} \mathrm{m}^{-2}\right)\end{array}$ & $-85.7 \pm 74$ & $-19.2 \pm 40$ & $24.8 \pm 25$ & $-7.3 \pm 2.1$ & $-183 \pm 39$ & $-910 \pm 61^{*}$ & $-663 \pm 16^{*}$ & $15.3 \pm 23$ & $-45 \pm 61$ & $-602 \pm 123^{*}$ \\
\hline $\begin{array}{l}\text { Final, enriched } \\
(\Delta \mathrm{Fe} \text { or } \Delta \mathrm{S}) \\
\left(\mathrm{mmol} \mathrm{m}^{-2}\right)\end{array}$ & $87.3 \pm 42$ & $39.1 \pm 11$ & $-24.8 \pm 1.5^{*}$ & $7.6 \pm 4.1$ & $329 \pm 92$ & $2088 \pm 194^{*}$ & $1776 \pm 135^{*}$ & $-114 \pm 23$ & $528 \pm 100^{*}$ & $1928 \pm 139^{*}$ \\
\hline
\end{tabular}

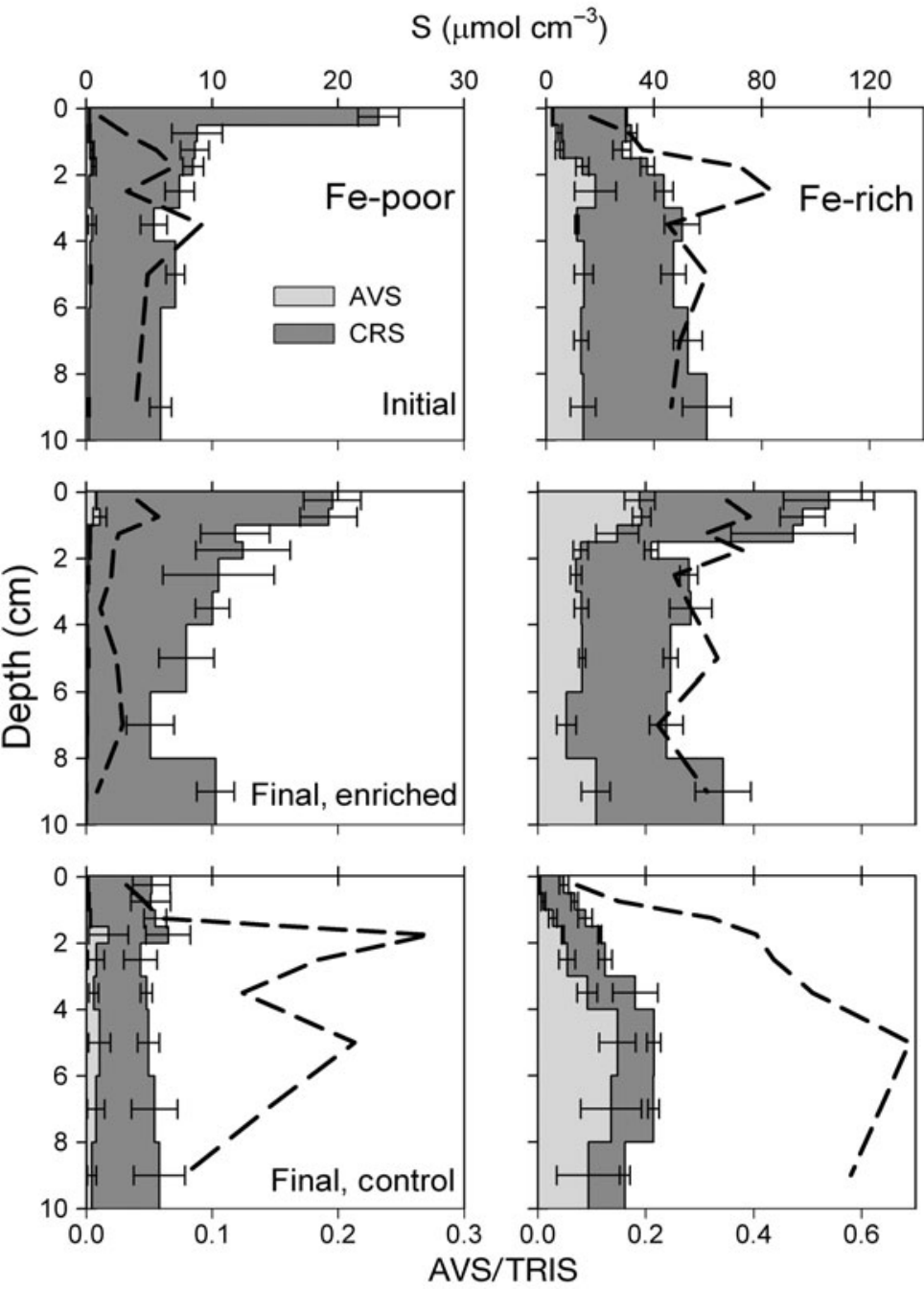

Fig. 8. Vertical profiles of accumulated acid volatile sulfides (AVS) and chromium reducible sulfides (CRS) in initial and final control cores (upper and lower panels, respectively) and enriched cores (middle panels). Left panels represent Fe-poor sediment and right panels represent Ferich sediment. Dashed lines indicate the ratio of reduced $\mathrm{S}$ bound in AVS $(\mathrm{AVS} /(\mathrm{AVS}+\mathrm{CRS}))$. Error bars indicate SE $(\mathrm{n}=3)$. TRIS: total reduced inorganic sulfides was constant in the upper $4 \mathrm{~cm}$ of initial Ferich controls at an average of $111 \pm 3 \mu \mathrm{mol}$ $\mathrm{cm}^{-3}$ followed by a level of 130 to $150 \mu \mathrm{mol}$ $\mathrm{cm}^{-3}$ below. RFe(III) decreased from $28 \pm$

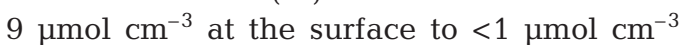
below $2 \mathrm{~cm}$ depth. RFe(III) was increased to $47 \pm 0.3 \mu \mathrm{mol} \mathrm{cm}{ }^{-3}$ in the upper $0.5 \mathrm{~cm}$ of final Fe-rich controls and TRFe was lower than initial values $\left(\sim 100 \mu \mathrm{mol} \mathrm{cm}{ }^{-3}\right)$, partly due to a lower contribution of pyriteFe. A TRFe peak was evident from 0 to $2 \mathrm{~cm}$ in enriched Fe-rich cores where concentrations reached $216 \mu \mathrm{mol}$ $\mathrm{cm}^{-3}$, primarily due to increased RFe(II) (Fig. 9). TRFe was relatively constant below

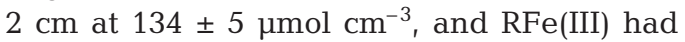
diminished in the upper part of enriched Ferich cores compared with controls.

\section{DISCUSSION}

\section{$S$ cycling in non-enriched and enriched sediment}

Stimulation of SR due to organic enrichment was spatially limited to the near-surface sediment with no apparent impact of infauna on OM distribution. SR increased 5 to 11 times in the upper $0.5 \mathrm{~cm}$ of enriched cores and remained similar to control levels below $1 \mathrm{~cm}$ depth. A similar depth-dependent variation of $\mathrm{SR}$ is frequently observed in sediments impacted by continuously high OM loading (e.g. beneath fish farms) (Holmer \& Kristensen 1992, Holmer \& Frederiksen 2007). However, SR can be stimulated to greater depths, either due to high OM deposition over longer time periods (years) than in the present experiment (Holmer \& Frederiksen 2007) or due to trans- 

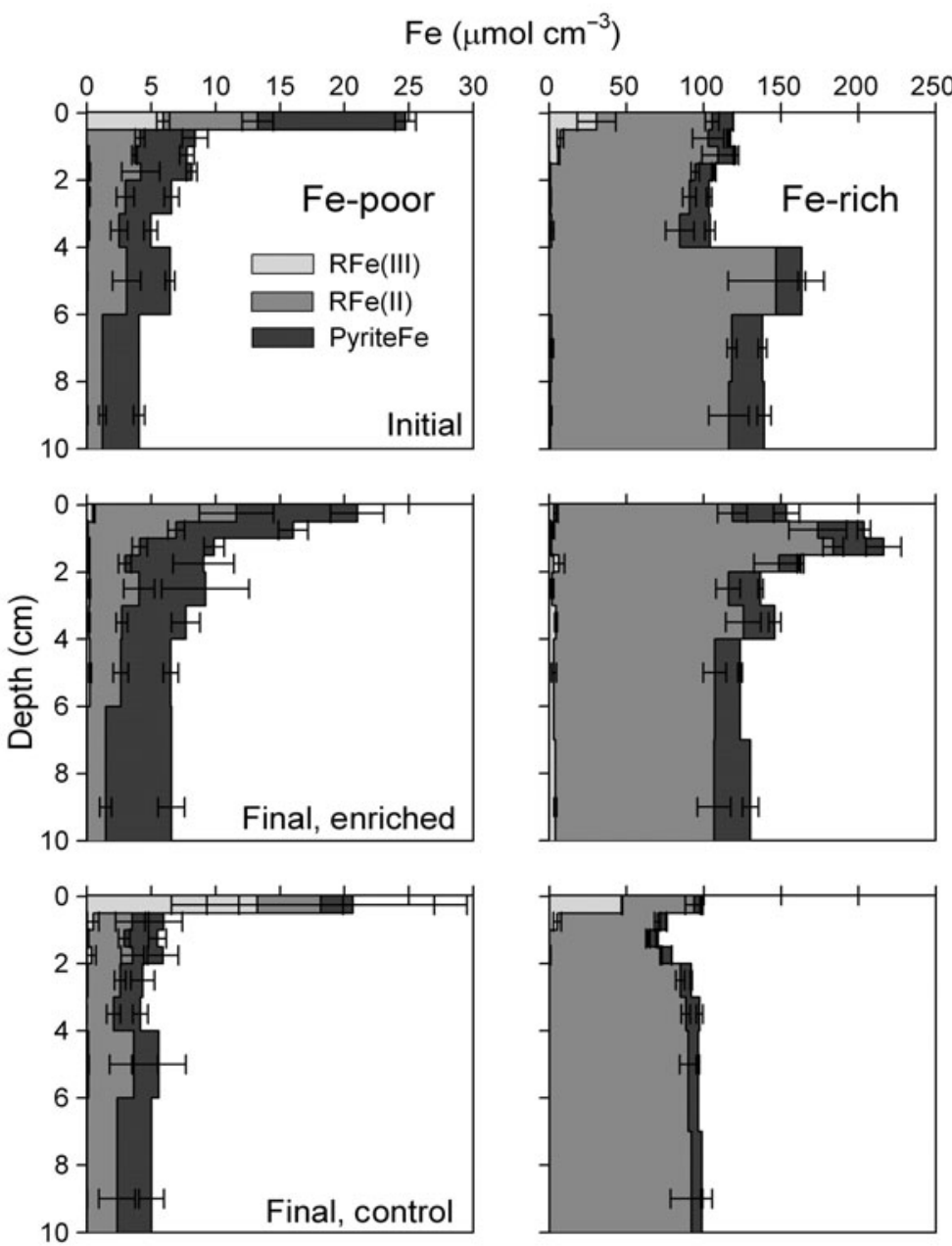

Fig. 9. Vertical profiles of accumulated reactive Fe(III) (RFe(III)), reactive $\mathrm{Fe}(\mathrm{II})(\mathrm{RFe}(\mathrm{II})$ ), and Fe bound in pyrite (pyriteFe) content in initial and final control cores (upper and lower panels, respectively) and enriched cores (middle panels). Left panels represent Fe-poor sediment and right panels represent Fe-rich sediment. Error bars indicate SE $(n=3)$

location of OM by infauna (Kristensen \& Mikkelsen 2003, Papaspyrou et al. 2004). We only added $9 \mathrm{~mm}$ of sediment on top of the initial sediment surface in the enrichment procedure. This roughly corresponds to the depth of elevated SR and POC in final enriched cores, suggesting that infauna had little impact on OM distribution. Similar observations have been made for the polychaetes Heteromastus filiformis and Marenzellaria viridis in an experiment where downward mixing of surface particles was quantified by the luminophore tracer technique (Quintana et al. 2007). The majority of added OM was therefore degraded by fermentation and subsequent respiration (e.g. SR) in the enriched surface layer.

The temporal development of $\mathrm{TH}_{2} \mathrm{~S}$ accumulation and fluxes in response to $\mathrm{OM}$ enrichment suggest a rapid response of microbial communities. After an initial lag phase, both fluxes and $\mathrm{TH}_{2} \mathrm{~S}$ accumulation increased to high levels that remained until the end. The short initial lag phase may represent the time needed for fermenting and respiring microbial communities to adapt to the increased availability of new substrates (Hansen \& Kristensen 1998), but may, with respect to $\mathrm{TH}_{2} \mathrm{~S}$, also reflect the time for depletion of the most reactive Fe. The oscillatory pattern of fluxes that followed repeated organic inputs and the steep chemical gradients of $\mathrm{TH}_{2} \mathrm{~S}$ observed after Day 20 (Fe-poor) and Day 10 (Fe-rich) indicates a tight coupling between organic enrichment and the numerous microbial, chemical, and physical processes involved.

Microprofiles of $\mathrm{TH}_{2} \mathrm{~S}$ and $\mathrm{O}_{2}$ demonstrated fine-scale effects of OM enrichment, which depend on the sediment type. Rapid $\mathrm{TH}_{2} \mathrm{~S}$ accumulation leads to lower $\mathrm{O}_{2}$ penetration due to high $\mathrm{O}_{2}$ demand for $\mathrm{TH}_{2} \mathrm{~S}$ oxidation, and the $\mathrm{TH}_{2} \mathrm{~S}$ profiles in enriched cores were characterized by a subsurface peak at 3 to $5 \mathrm{~mm}$ depth, a steep upward gradient towards the sediment surface and a less steep downward gradient. The profiles indicated $\mathrm{TH}_{2} \mathrm{~S}$ accumulation to $1.5 \mathrm{~cm}$ depth, which coincided with the zone of stimulated SR in final enriched cores. The steep upward $\mathrm{TH}_{2} \mathrm{~S}$ gradients in both sediments are indicative of $\mathrm{TH}_{2} \mathrm{~S}$ reoxidation, either though spontaneous reoxidation with $\mathrm{O}_{2}$ or Fe oxides or microbially mediated reoxidation with $\mathrm{O}_{2}$ or $\mathrm{NO}_{3}^{-}$(Fossing et al. 1995, Sayama et al. 2005, Preisler et al. 2007). In Fe-poor sediment, $\mathrm{TH}_{2} \mathrm{~S}$ was present to the sediment surface and was probably oxidized in the $<0.5 \mathrm{~mm}$ overlap zone between $\mathrm{O}_{2}$ and $\mathrm{TH}_{2} \mathrm{~S}$ at the sediment surface, which is similar to observations from other organically rich, low-Fe sediments (Tankere et al. 2002). In contrast, the upward concave curvature in Fe-rich sediment suggested a $<2 \mathrm{~mm}$ thick suboxic zone where $\mathrm{TH}_{2} \mathrm{~S}$ oxidation may occur with Fe oxides or $\mathrm{NO}_{3}^{-}$. The importance of biological versus chemical reoxidation could not be estimated in the present study, but 3 to $50 \%$ of total $\mathrm{TH}_{2} \mathrm{~S}$ reoxidation has been attributed to the activity of Beggiatoa spp. in previous studies (Mussmann et al. 2003, Preisler et al. 2007). When considering the $\mathrm{mM}$ levels of $\mathrm{TH}_{2} \mathrm{~S}$ in surface sediment and the duration of the experiment, the downward distribution of $\mathrm{TH}_{2} \mathrm{~S}$ was far less than that predicted by passive diffusion in both sediments. $\mathrm{TH}_{2} \mathrm{~S}$ accumulation was probably modified by bioturbation and precipitation with $\mathrm{Fe}$, and whereas infauna may have facilitated subsurface $\mathrm{TH}_{2} \mathrm{~S}$ oxidation in both sediment types, precipitation with Fe was only quantitatively important in Fe-rich sediment. 
It appeared that the importance of SR for total C oxidation varied in the 2 sediment types, with higher importance in Fe-poor sediment. Final depth-integrated SR measured $7 \mathrm{~d}$ after final enrichments was 31 and $36 \mathrm{mmol} \mathrm{SO}_{4}{ }^{2-} \mathrm{m}^{-2} \mathrm{~d}^{-1}$ in Fe-poor and Fe-rich sediment, respectively, which corresponds to 82 and $40 \%$ of $\mathrm{C}$ oxidation measured $5 \mathrm{~d}$ after final enrichments (assuming a 2:1 C:S stoichiometry during SR). However, with regard to total integrated $\mathrm{TCO}_{2}$ efflux (Table 2), the measured SR only corresponds to 39 and $33 \%$, respectively. Both estimates suggest that SR was more important for $\mathrm{C}$ oxidation in Fe-poor sediment, whereas other processes (e.g. Fe reduction and aerobic respiration) probably contributed significantly more in Fe-rich sediment. These results support the much lower SR typically found in bioirrigated and/or Fe-rich sediments (Banta et al. 1999, Heilskov \& Holmer 2001, 2003, Jensen et al. 2003) as opposed to the greater importance of SR in organically enriched defaunated sediments (Heilskov \& Holmer 2001, Holmer \& Frederiksen 2007, Valdemarsen et al. 2009). The relatively low final SR measured at the end also contradicts the steep $\mathrm{TH}_{2} \mathrm{~S}$ gradients measured by microelectrodes during the experiment, which suggested much higher rates. The upward and downward diffusion can be calculated according to Fick's first law (Thamdrup et al. 1994):

$$
J=-\phi D_{\mathrm{s}} \frac{\mathrm{d} C}{\mathrm{~d} x}
$$

where $J$ is diffusive flux, $\phi$ is sediment porosity, $(\mathrm{d} C / \mathrm{d} x)$ is the diffusion gradient and $D_{\mathrm{s}}$ is the sediment diffusion coefficient calculated for sediments with $\varphi<0.7$ according to Ullman \& Aller (1982):

$$
D_{\mathrm{s}}=\phi^{-2} D_{\mathrm{w}}
$$

where $D_{\mathrm{w}}$ is the diffusion coefficient for $\mathrm{TH}_{2} \mathrm{~S}$ in water (Li \& Gregory 1974). Thus, the sum of upward and downward diffusion suggests that SR $( \pm$ SE) was $70 \pm$ 10 and $60 \pm 8 \mathrm{mmol} \mathrm{SO}{ }^{2-} \mathrm{m}^{-2} \mathrm{~d}^{-1}$ in Fe-poor and Ferich sediment, corresponding to 88 and $54 \%$ of total $\mathrm{C}$ oxidation, respectively. These estimates have inherent uncertainties because $\mathrm{TH}_{2} \mathrm{~S}$ probably is oxidized and precipitated in the entire enriched layer (Thamdrup et al. 1994) and porewater transport is enhanced by irrigation. Our estimates are particularly sensitive to the latter, because recent results show significant porewater advection in sediment inhabited by Marenzellaria viridis (M. Delefosse et al. unpubl.). Since $M$. viridis was present in all enriched cores, porewater advection may have vertically compressed $\mathrm{TH}_{2} \mathrm{~S}$ gradients, causing diffusive estimates of SR to be overestimates. Nonetheless, when SR obtained by radiotracer assays were compared to temporally close measurements of $\mathrm{TCO}_{2}$ effluxes, the importance of SR for total C oxidation is similar to those obtained from $\mathrm{TH}_{2} \mathrm{~S}$ micropro- files. Since microprofiles were typically measured 2 to $3 \mathrm{~d}$ after enrichments and final radiotracer measurements were conducted $7 \mathrm{~d}$ later, the difference between absolute values of SR (i.e. 31 and $70 \mathrm{mmol} \mathrm{m}^{-2}$ $\mathrm{d}^{-1}$ measured by different techniques 7 and 2 to $3 \mathrm{~d}$ after enrichment in Fe-poor sediment) can be explained by a rapid time-dependent attenuation of SR due to depletion of the most labile substrates (Valdemarsen et al. 2009). Rate constants predicted from this rate attenuation $\left(0.15\right.$ to $\left.0.2 \mathrm{~d}^{-1}\right)$ corresponds well to other studies where labile OM was degraded by SR (Westrich \& Berner 1984, Kristensen \& Holmer 2001).

\section{Fe-sulfide interactions and sulfide buffering}

Fe-sulfide interactions were quantitatively important in Fe-rich sediment where TRIS precipitated in the zone of stimulated SR. The TRIS buildup of $38 \mathrm{mmol} \mathrm{S}$ $\mathrm{m}^{-2} \mathrm{~d}^{-1}$ was equivalent to $63 \%$ of all produced $\mathrm{TH}_{2} \mathrm{~S}$ during the 9 wk period assuming that $54 \%$ of $\mathrm{C}$ oxidation estimated from effluxes was SR as discussed above. The presence of infauna clearly maintained oxic and suboxic conditions, pushing $\mathrm{TH}_{2} \mathrm{~S}$ accumulation $2 \mathrm{~mm}$ downward. Simultaneously, the increased availability of iron in surface sediment (see below) facilitated an efficient precipitation of produced $\mathrm{TH}_{2} \mathrm{~S}$. It is puzzling, however, that mM levels of $\mathrm{TH}_{2} \mathrm{~S}$ coincided with $>200 \mu \mathrm{M} \mathrm{Fe}{ }^{2+}$ near the surface of final enriched Fe-rich cores, since TRIS precipitates readily when both $\mathrm{Fe}^{2+}$ and $\mathrm{TH}_{2} \mathrm{~S}$ are present at $\mu \mathrm{M}$ levels (Rickard 1995, Rickard \& Morse 2005). Fe-sulfide clusters $<0.8 \mu \mathrm{m}$ may have passed through GF/F filters and dissolved upon acidification of samples for dissolved $\mathrm{Fe}^{2+}$. Alternatively, the generally observed mosaic of oxic and anoxic microniches in bioturbated sediments (Fenchel 1996, Kristensen 2000, Nielsen et al. 2003) may have prevented TRIS formation due to small-scale $\mathrm{Fe}^{2+}$ or $\mathrm{TH}_{2} \mathrm{~S}$ limitation. In any case, the level of TRIS precipitation was $18 \%$ higher than observed in diffusion-controlled defaunated sediment (Valdemarsen et al. 2009) (Fig. 10), where no suboxic zone was observed and TRIS precipitation was limited by upwards diffusion of $\mathrm{Fe}^{2+}$, leading to increased $\mathrm{TH}_{2} \mathrm{~S}$ oxidation with $\mathrm{O}_{2}$ at the sediment-water interface.

In Fe-rich enriched cores it appeared that infauna stimulated transport of iron from the deeper sediment towards the sediment surface. TRFe increased by $48 \%$ in the upper $4 \mathrm{~cm}$, corresponding to an upward Fe flux $>30$ times higher than previously estimated for diffusion-controlled Fe-rich sediments (Thamdrup et al. 1994, Valdemarsen et al. 2009). Thus, Valdemarsen et al. (2009) found that $\mathrm{Fe}^{2+}$ for TRIS formation was primarily mobilized within the zone of SR. Our results suggest that Fe is transported in bioturbated sediment, presumably as $\mathrm{Fe}^{2+}$ 

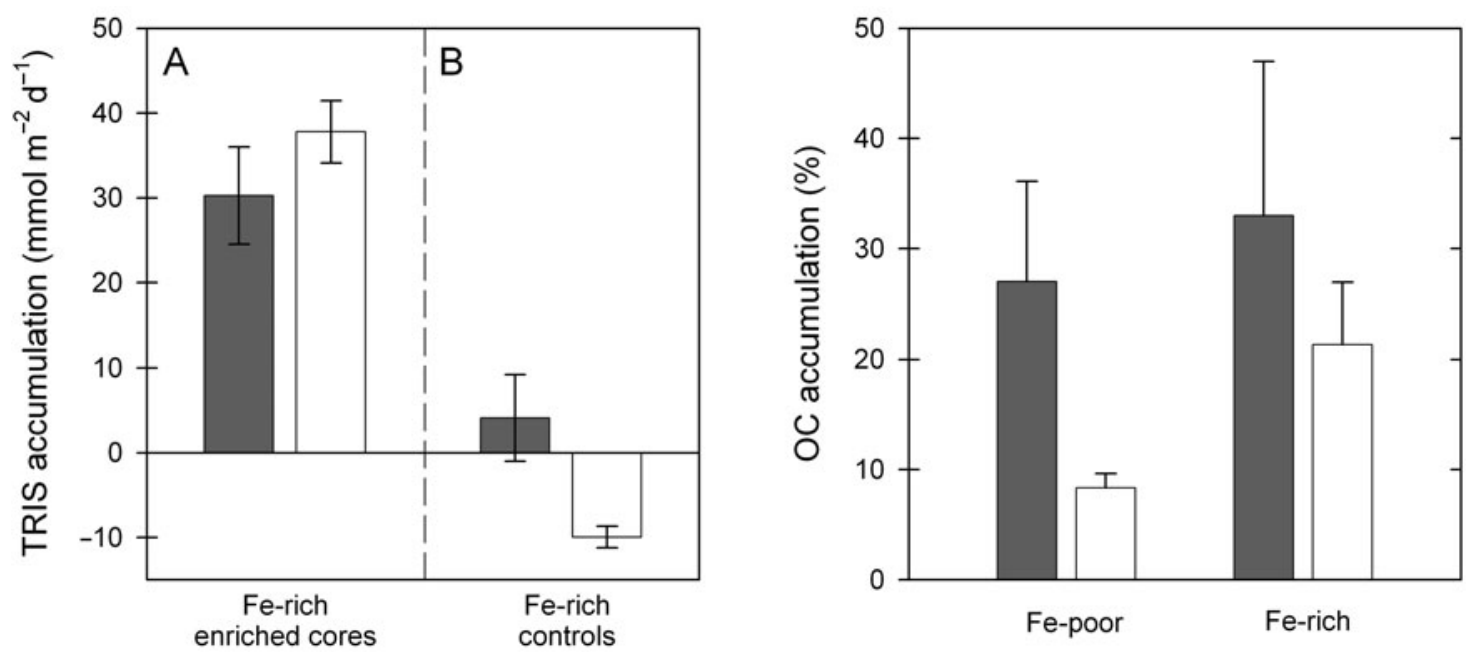

Fig. 10. Average total reduced inorganic sulfide (TRIS) buildup in (A) Fe-rich enriched and (B) control sediment (left panel) and accumulation of added organic carbon (OC) (right panel). Results are shown for both the present experiment ( $\square$ ) and the diffusion-controlled experiment of Valdemarsen et al. (2009) ( $\square$ ). Error bars represent SE (n = 3)

within anoxic interstitial waters by irrigation-induced porewater advection. Thus, the Fe-based $\mathrm{TH}_{2} \mathrm{~S}$ buffer may be greatly prolonged in bioturbated sediments due to an increased availability of $\mathrm{Fe}^{2+}$. For example, in Ferich sediment the rate of TRIS formation in the present study could only be sustained for $72 \mathrm{~d}$ if $50 \%$ of initial $\mathrm{RFe}$ (II) (ratio similar to Heijs et al. 1999) from the 0 to $2 \mathrm{~cm}$ interval was available for precipitation. However, if infauna facilitates mobilization of $\mathrm{Fe}^{2+}$ from sediment down to $10 \mathrm{~cm}$ depth, the rate of TRIS formation can potentially be sustained for $375 \mathrm{~d}$. It has similarly been estimated that TRIS formation can be sustained for up to $160 \mathrm{~d}$ in a eutrophic coastal lagoon with high SR (Heijs et al. 1999, 2000) and up to $120 \mathrm{~d}$ in diffusion-controlled sediment mesocosms (Valdemarsen et al. 2009).

Our results show that Fe-driven sulfide buffering is a significant process capable of mitigating $\mathrm{TH}_{2} \mathrm{~S}$ buildup in Fe-rich sediments. However, continuous $\mathrm{TH}_{2} \mathrm{~S}$ buffering requires periodic regeneration of reactive Fe. Reoxidation of TRIS may occur during seasonal lows in benthic metabolism (e.g. during winter in temperate regions or during fallowing beneath fish farms) and through resuspension events and bioturbation (Chareonpanich et al. 1994, Thamdrup et al. 1994). In the parallel experiment of Valdemarsen et al. (2009) no TRIS reoxidation was observed in defaunated control sediment for $>40 \mathrm{~d}$. Therefore the much lower TRIS observed in final Fe-rich controls in the present experiment (Fig. 10) is interpreted as infauna-driven TRIS reoxidation. However, TRIS reoxidation in faunated controls occurred at relatively low rates $\left(\sim 10 \mathrm{mmol} \mathrm{S} \mathrm{m}^{-2} \mathrm{~d}^{-1}\right.$ corresponding to $26 \% \mathrm{~d}^{-1}$ of TRIS formation in Fe-rich enriched cores), which indicates that regeneration of the $\mathrm{TH}_{2} \mathrm{~S}$-buffering capacity is a relatively slow process despite low benthic metabolism and fauna-driven irrigation.
No significant iron-sulfide interactions were observed in Fe-poor sediment, but trends in TRIS and Fe pools for both final control and enriched cores were similar to changes observed in Fe-rich sediment (i.e. increased levels of TRFe, AVS, and CRS in final enriched cores and lower levels in final controls). Iron-sulfide interactions therefore seem to be governed by similar mechanisms in both sediments. However, our results suggest that significant $\mathrm{TH}_{2} \mathrm{~S}$ buffering is only quantitatively important in sediments with Fe content much greater than $3 \mu \mathrm{mol} \mathrm{cm}{ }^{-3}$ (i.e. the Fe level in Fe-poor sediment).

\section{Impact of organic enrichment on $\mathrm{C}$ and $\mathrm{N}$ mineralization}

Organic enrichments led to a rapid increase in total benthic metabolism evidenced by a 5 and 8 times stimulation of $\mathrm{TCO}_{2}$ release after $10 \mathrm{~d}$ in $\mathrm{Fe}$-poor and Fe-rich sediment, respectively. Most of the stimulation was probably due to microbial processes, since the role of macrofauna respiration for total C oxidation is generally minor in organically enriched sediments (Banta et al. 1999, Heilskov \& Holmer 2001, Heilskov et al. 2006). However, the much lower faunal densities in final controls compared to final enriched cores suggest that the added OM was vital as a food source for the infauna in enriched cores.

There were large deficits in $\mathrm{C}$ and $\mathrm{N}$ budgets, since $\mathrm{TCO}_{2}$ and $\mathrm{NH}_{4}{ }^{+}$release only accounted for 34 to $56 \%$ and 40 to $46 \%$ of added OC and ON, respectively, whereas POC and TN data suggested much higher mineralization $(>78 \%)$. Similar deficits in response to organic enrichments were observed by Valdemarsen et al. 
(2009), and they suggested an exponential decay of the most labile substrates between enrichments, causing high and undetected $\mathrm{TCO}_{2}$ and $\mathrm{NH}_{4}{ }^{+}$release right after enrichments followed by rapid attenuation between enrichments as discussed for SR (see discussion above). Hence, flux measurements did not capture the initial metabolite release causing deficits in $\mathrm{C}$ and $\mathrm{N}$ budgets. A similar trend can be expected in the present experiment, although the oscillations were not as pronounced as in Valdemarsen et al. (2009) probably due to infauna irrigation. Furthermore, Valdemarsen et al. (2009) measured a diffusive loss of DOC and dissolved organic nitrogen (DON) right after enrichments, corresponding to 3 to $5 \%$ and $2 \%$ of added $C$ and $N$, respectively. The diffusive loss was not estimated in the present experiment, but a small fraction of added $\mathrm{C}$ and $\mathrm{N}$ was probably lost to the overlying water without prior mineralization.

Porewater profiles and vertical distribution of SR support the contention that organic enrichment primarily stimulates mineralization processes in the upper $1 \mathrm{~cm}$. Based on depletion of POC and TN, average mineralization of $\mathrm{C}$ and $\mathrm{N}$ in the upper $1 \mathrm{~cm}$ of enriched cores approached 25 to 31 and $3 \mu \mathrm{mol} \mathrm{cm} \mathrm{cm}^{-3} \mathrm{~d}^{-1}$, respectively. These rates are extreme compared to closed sediment incubations enriched with fish feed ( 0.2 to $5 \mathrm{C}$ and 0.2 to $1 \mathrm{~N} \mathrm{\mu mol} \mathrm{cm}{ }^{-3} \mathrm{~d}^{-1}$ ) (Holmer \& Kristensen 1994a, b), where the initial hydrolysis was probably hampered by accumulation of fermentation products (e.g. DOC and $\mathrm{H}_{2}$ ) (Canfield et al. 2005). In the present experiment, accumulation of inhibitory metabolites and depletion of electron acceptors in the upper $1 \mathrm{~cm}$ was prevented by irrigation and close contact between enriched sediment and overlying water (Aller \& Aller 1998, Valdemarsen \& Kristensen 2005). Thus, mineralization can occur at maximum rates governed by substrate quality. Our results are therefore comparable to those (3 to $26 \mathrm{C}$ and 1 to $2.2 \mathrm{~N} \mu \mathrm{mol} \mathrm{cm} \mathrm{cm}^{-3} \mathrm{~d}^{-1}$ ) measured in thin-layer incubations enriched with diatom or hay detritus (Kristensen \& Holmer 2001) or mesocosms enriched at the sediment surface with baker's yeast (Sloth et al. 1995) or fish feed (Valdemarsen et al. 2009).

Based on TN accumulation, $\mathrm{N}$ mineralization of added OM was complete in Fe-poor sediment, whereas $22 \%$ of added ON accumulated in Fe-rich enriched cores. C mineralization was also enhanced in Fe-poor sediment, since only $8.4 \%$ of added OC accumulated as opposed to $21 \%$ in Fe-rich sediment. Our results for $\mathrm{N}$ are similar to those of Valdemarsen et al. (2009), who observed 4 to $13 \% \mathrm{~N}$ accumulation, and indicate that system openness (infaunal irrigation and proximity to interfaces) has little effect on N mineralization (Kristensen \& Hansen 1995, Sloth et al. 1995). Several studies have demonstrated that $\mathrm{N}$ mineralization can proceed at high rates, even when $\mathrm{C}$ mineralization is hampered by accumulation of fermentation products (Holmer \& Kristensen 1994a, Kristensen
\& Hansen 1995); $\mathrm{N}$ mineralization in the present study may be less affected by changed redox conditions due to macrofauna. C mineralization, on the other hand, appears to be enhanced by infaunal activities, as indicated by lower POC accumulation than observed by Valdemarsen et al. (2009) for defaunated sediment (only significant for Fe-poor sediment; Fig. 10). Aerobic and anaerobic mineralization of labile organic compounds usually occur at similar rates, while partly refractory POC is mineralized much faster under oxic conditions (Kristensen et al. 1995, Hulthe et al. 1998, Kristensen \& Holmer 2001). Since irrigation increases the oxic sediment volume (Kristensen \& Holmer 2001), POC accumulation in the sediment of the present study must be lower than that reported by Valdemarsen et al. (2009), who observed 27 and $33 \%$ accumulation of added $\mathrm{C}$ in Fe-poor and Fe-rich sediment, respectively. Furthermore, in the present experiment the much higher irrigation observed in Fe-poor sediment may explain the relatively lower POC accumulation in Fe-poor sediment compared to that in Fe-rich sediment.

\section{Environmental implications}

Is the presently applied organic loading sustainable in sediments affected by deposition of fish farm waste products under the given levels of water phase mixing and infauna densities? Several authors suggest that no OM should accumulate below the sustainable threshold (Findlay \& Watling 1997, Kutti et al. 2008), and based on this criterion the sustainable threshold is surpassed in Fe-rich and Fe-poor sediments. However, the OM properties and the controls of OM degradation determine the long-term impact of OM accumulation. If accumulated OM represents a slowly degradable residue, the present loading rate may be maintained for extended time, without $\mathrm{TH}_{2} \mathrm{~S}$ accumulation and increased levels of fluxes. Eventually, OM content will increase gradually to a new steady-state level if the maximum metabolic capacity of microbial communities is not surpassed (Valdemarsen et al. 2009). If and when the metabolic capacity is exceeded by continuous enrichment, a gradual accumulation of labile OM will be associated with massive $\mathrm{TH}_{2} \mathrm{~S}$ accumulation and effluxes. In diffusion-controlled sediments, the sustainable threshold is the point where the $\mathrm{O}_{2}$ demand for $\mathrm{TH}_{2} \mathrm{~S}$ oxidation is balanced by the maximum diffusive SOU (i.e. no $\mathrm{TH}_{2} \mathrm{~S}$ release to the water column). Since the presence of infauna greatly stimulates transport of $\mathrm{O}_{2}$ into sediments, the sustainable threshold will be higher in faunated sediments. Benthic infauna may also, however, promote $\mathrm{TH}_{2} \mathrm{~S}$ accumulation in deeper layers by downward mixing of reactive OM. This effect is not crucial here, but may be 
important in sediments with more intense sediment reworking.

We have in the present study simulated the previously reported upper threshold for OM enrichment ( $\left.400 \mathrm{mmol} \mathrm{C} \mathrm{m}^{-2} \mathrm{~d}^{-1}\right)$ above which adverse effects are noticed on infaunal diversity and production (Findlay \& Watling 1997, Hargrave et al. 2008, Kutti et al. 2008). Despite strongly stimulated benthic metabolism, $\mathrm{TH}_{2} \mathrm{~S}$ accumulation and occurrence of Beggiatoa spp. at the sediment surface, infauna thrived in enriched sediment. This contrasting result indicates that the threshold for OM enrichment should not be defined in terms of the organic input, but rather in terms of the metabolic capacity of sediments. Oxidizing effects caused by fauna and sulfide precipitation in Fe-rich sediments may extend the metabolic capacity beyond the expected threshold for OM loading. Our results confirm that well established infaunal communities can counteract the effects of surface enrichment. It is therefore important to consider faunal abundance and composition as well as the availability of reactive iron when the threshold for OM loading or rather the metabolic capacity is determined for marine sediments.

Acknowledgements. We thank B. Christensen, M. Delefosse, and K. Povidisa for assistance in the laboratory. This work was funded by EU project Thresholds, contract no. 003933.

\section{LITERATURE CITED}

Aller RC (1994) Bioturbation and remineralization of sedimentary organic matter: effects of redox oscillation. Chem Geol 114:331-345

Aller RC, Aller JY (1998) The effect of biogenic irrigation intensity and solute exchange on diagenetic reaction rates in marine sediments. J Mar Res 56:905-936

Banta GT, Holmer M, Jensen MH, Kristensen E (1999) Effects of two polychaete worms, Nereis diversicolor and Arenicola marina, on aerobic and anaerobic decomposition in a sandy marine sediment. Aquat Microb Ecol 19:189-204

> Bower CE, Holm-Hansen T (1980) A salicylate-hypochlorite method for determining ammonia in seawater. Can J Fish Aquat Sci 37:794-798

Canfield DE (1989) Reactive iron in marine sediments. Geochim Cosmochim Acta 53:619-632

Canfield DE (1994) Factors influencing organic matter preservation in marine sediments. Chem Geol 114:315-329

Canfield DE, Thamdrup B, Kristensen E (2005) Aquatic geomicrobiology. Elsevier Academic Press, San Diego, CA

> Chareonpanich C, Tsutsumi H, Montani S (1994) Efficiency of the decomposition of organic matter, loaded on the sediment, as a result of the biological activity of Capitella sp. I. Mar Pollut Bull 28:314-318

Cline JD (1969) Spectrophotometric determination of hydrogen sulfide in natural waters. Limnol Oceanogr 14:454-458

Fenchel $\mathrm{T}$ (1996) Worm burrows and oxic microniches in marine sediments. 1. Spatial and temporal scales. Mar Biol 127:289-295

Findlay RH, Watling L (1997) Prediction of benthic impact for salmon net-pens based on the balance of benthic oxygen supply and demand. Mar Ecol Prog Ser 155:147-157
Fossing H, Jørgensen BB (1989) Measurement of bacterial sulfate reduction in sediments: evaluation of a single-step chromium reduction method. Biogeochemistry 8:205-222

Fossing H, Gallardo VA, Jorgensen BB, Huttel M and others (1995) Concentration and transport of nitrate by the matforming sulfur bacterium Thioploca. Nature 374:713-715

Giles H, Pilditch CA, Bell DG (2006) Sedimentation from mussel (Perna canaliculus) culture in the Firth of Thames, New Zealand: impacts on sediment oxygen and nutrient fluxes. Aquaculture 261:125-140

Giordani G, Azzoni R, Viaroli P (2008) A rapid assessment of the sedimentary buffering capacity towards free sulphides. Hydrobiologia 611:55-66

Glud RN, Gundersen JK, Ramsing NB (2000) Electrochemical and optical oxygen microsensors for in situ measurements. In: Buffle J, Horvai G (eds) In situ monitoring of aquatic systems: general analysis and speciation. John Wiley \& Sons, New York, p 19-73

Hall POJ, Aller RC (1992) Rapid, small-volume, flow injection analysis for $\Sigma \mathrm{CO}_{2}$ and $\mathrm{NH}_{4}{ }^{+}$in marine and freshwaters. Limnol Oceanogr 37:1113-1119

> Hansen K, Kristensen E (1998) The impact of the polychaete Nereis diversicolor and enrichment with macroalgal (Chaetomorpha linum) detritus on benthic metabolism and nutrient dynamics in organic-poor and organic-rich sediment. J Exp Mar Biol Ecol 231:201-233

Hargrave BT, Holmer M, Newcombe CP (2008) Towards a classification of organic enrichment in marine sediments based on biogeochemical indicators. Mar Pollut Bull 56: $810-824$

Heijs SK, Jonkers HM, van Gemerden H, Schaub BEM, Stal LJ (1999) The buffering capacity towards free sulphide in sediments of a coastal lagoon (Bassin d'Arcachon, France) - the relative importance of chemical and biological processes. Estuar Coast Shelf Sci 49:21-35

> Heijs SK, Azzoni R, Giordani G, Jonkers HM, Nizzoli D, Viaroli P, van Gemerden H (2000) Sulfide-induced release of phosphate from sediments of coastal lagoons and the possible relation to the disappearance of Ruppia sp. Aquat Microb Ecol 23:85-95

Heilskov AC, Holmer M (2001) Effects of benthic fauna on organic matter mineralization in fish-farm sediments: importance of size and abundance. ICES J Mar Sci 58: $427-434$

Heilskov AC, Holmer M (2003) Influence of benthic fauna on organic matter decomposition in organic-enriched fish farm sediments. Vie Milieu 53:153-161

> Heilskov AC, Alperin M, Holmer M (2006) Benthic fauna bioirrigation effects on nutrient regeneration in fish farm sediments. J Exp Mar Biol Ecol 339:204-225

Holmer M, Frederiksen MS (2007) Stimulation of sulfate reduction rates in Mediterranean fish farm sediments inhabited by the seagrass Posidonia oceanica. Biogeochemistry 85:169-184

Holmer M, Kristensen E (1992) Impact of marine fish cage farming on metabolism and sulfate reduction of underlying sediments. Mar Ecol Prog Ser 80:191-201

> Holmer M, Kristensen E (1994a) Organic matter mineralization in an organic-rich sediment: experimental stimulation of sulfate reduction by fish food pellets. FEMS Microbiol Ecol 14:33-44

Holmer M, Kristensen E (1994b) Coexistence of sulfate reduction and methane production in an organic-rich sediment. Mar Ecol Prog Ser 107:177-184

> Holmer M, Marba N, Terrados J, Duarte CM, Fortes MD (2002) Impacts of milkfish (Chanos chanos) aquaculture on carbon and nutrient fluxes in the Balinao area, Philippines. Mar Pollut Bull 44:685-696 
Holmer M, Marba N, Diaz-Almela E, Duarte CM, Tsapakis M, Danovaro R (2007) Sedimentation of organic matter from fish farms in oligotrophic Mediterranean assessed through bulk and stable isotope $\left(\delta^{13} \mathrm{C}\right.$ and $\left.\delta^{15} \mathrm{~N}\right)$ analyses. Aquaculture 262:268-280

Hulthe G, Hulth S, Hall POJ (1998) Effect of oxygen on degradation rate of refractory and labile organic matter in continental margin sediments. Geochim Cosmochim Acta 62:1319-1328

Inman DL (1952) Measures for describing size distribution of sediments. J Sediment Petrol 22:125-145

> Jensen MM, Thamdrup B, Rysgaard S, Holmer M, Fossing H (2003) Rates and regulation of microbial iron reduction in sediments of the Baltic-North Sea transition. Biogeochemistry 65:295-317

Jeroschewski P, Steuckart C, Kuhl M (1996) An amperometric microsensor for the determination of $\mathrm{H}_{2} \mathrm{~S}$ in aquatic environments. Anal Chem 68:4351-4357

Karle IM, Hall POJ, Dahllöf I (2007) Biogeochemical response of an intact coastal sediment to organic matter input: a multivariate approach. Mar Ecol Prog Ser 342:15-25

Kristensen E (2000) Organic matter diagenesis at the oxic/ anoxic interface in coastal marine sediments, with emphasis on the role of burrowing animals. Hydrobiologia 426:1-24

Kristensen E (2001) Impact of polychaetes (Nereis spp. and Arenicola marina) on carbon biogeochemistry in coastal marine sediments. Geochem Trans 2:92

Kristensen E, Andersen FO (1987) Determination of organic carbon in marine sediments: a comparison of two CHNanalyzer methods. J Exp Mar Biol Ecol 109:15-23

Kristensen E, Hansen K (1995) Decay of plant detritus in organic-poor marine sediment: production rates and stoichiometry of dissolved C and N compounds. J Mar Res 53: 675-702

Kristensen E, Holmer M (2001) Decomposition of plant materials in marine sediment exposed to different electron acceptors $\left(\mathrm{O}_{2}, \mathrm{NO}_{3}^{-}\right.$, and $\left.\mathrm{SO}_{4}^{2-}\right)$, with emphasis on substrate origin, degradation kinetics, and the role of sulfate reduction. Geochim Cosmochim Acta 65:419-433

Kristensen E, Mikkelsen OL (2003) Impact of the burrowdwelling polychaete Nereis diversicolor on the degradation of fresh and aged macroalgal detritus in a coastal marine sediment. Mar Ecol Prog Ser 265:141-153

Kristensen E, Ahmed SI, Devol AH (1995) Aerobic and anaerobic decomposition of organic matter in marine sediment: Which is fastest? Limnol Oceanogr 40:1430-1437

Kutti T, Ervik A, Hansen PK (2007) Effects of organic effluents from a salmon farm on a fjord system. I. Vertical export and dispersal processes. Aquaculture 262:367-381

Kutti T, Ervik A, Høisæter T (2008) Effects of organic effluents form a salmon farm on a fjord system. III. Linking deposition rates of organic matter and benthic productivity. Aquaculture 282:47-53

Li YH, Gregory S (1974) Diffusion of ions in sea water and in deep-sea sediments. Geochim Cosmochim Acta 38:703-714

Lovley DR, Phillips EJP (1987) Rapid assay for microbially reducible ferric iron in aquatic sediments. Appl Environ Microbiol 53:1536-1540

Macleod CK, Crawford CM, Moltschaniwskyj NA (2004) Assessment of long term change in sediment condition after organic enrichment: defining recovery. Mar Pollut Bull 49:79-88

- Mascaro O, Valdemarsen T, Holmer M, Perez M, Romero J (2009) Experimental manipulation of sediment organic content and water column aeration reduces Zostera marina (eelgrass) growth and survival. J Exp Mar Biol Ecol 373:26-34

Mussmann M, Schulz HN, Strotmann B, Kjaer T and others (2003) Phylogeny and distribution of nitrate-storing Beggiatoa spp. in coastal marine sediments. Environ Microbiol 5:523-533

Nielsen OI, Kristensen E, Holmer M (2003) Impact of Arenicola marina (Polychaeta) on sediment sulfur dynamics. Aquat Microb Ecol 33:95-105

Papaspyrou S, Thessalou-Legaki M, Kristensen E (2004) Impact of Pestarella tyrrhena on benthic metabolism in sediment microcosms enriched with seagrass and macroalgal detritus. Mar Ecol Prog Ser 281:165-179

Pedersen AGU, Berntsen J, Lomstein BA (1999) The effect of eelgrass decomposition on sediment carbon and nitrogen cycling: a controlled laboratory experiment. Limnol Oceanogr 44:1978-1992

> Porrello S, Tomassetti P, Manzueto L, Fionia MG, Persia E, Mercatali I, Stipa P (2005) The influence of marine cages on the sediment chemistry in the Western Mediterranean Sea. Aquaculture 249:145-158

Preisler A, de Beer D, Lichtschlag A, Lavik G, Boetius A, Jorgensen BB (2007) Biological and chemical sulfide oxidation in a Beggiatoa inhabited marine sediment. ISME J 1:341-353

Quintana CO, Tang M, Kristensen E (2007) Simultaneous study of particle reworking, irrigation transport and reaction rates in sediment bioturbated by the polychaetes Heteromastus and Marenzelleria. J Exp Mar Biol Ecol 352:392-406

> Rickard D (1995) Kinetics of FeS precipitation: part 1. Competing reaction mechanisms. Geochim Cosmochim Acta 59:4367-4379

> Rickard D, Morse JW (2005) Acid volatile sulfide (AVS). Mar Chem 97:141-197

- Sayama M, Risgaard-Petersen N, Nielsen LP, Fossing $H_{\text {, }}$ Christensen PB (2005) Impact of bacterial $\mathrm{NO}_{3}{ }^{-}$transport on sediment biogeochemistry. Appl Environ Microbiol 71: 7575-7577

Schippers A, Jørgensen BB (2002) Biogeochemistry of pyrite and iron sulfide oxidation in marine sediments. Geochim Cosmochim Acta 66:85-92

Sloth NP, Blackburn H, Hansen LS, Risgaard-Petersen N, Lomstein BA (1995) Nitrogen cycling in sediments with different organic loading. Mar Ecol Prog Ser 116:163-170

> Stookey LL (1970) Ferrozine-a new spectrophotometric reagent for iron. Anal Chem 42:779-781

Tankere SPC, Bourne DG, Muller FLL, Torsvik V (2002) Microenvironments and microbial community structure in sediments. Environ Microbiol 4:97-105

Thamdrup B, Fossing H, Jørgensen BB (1994) Manganese, iron and sulfur cycling in a coastal marine sediment, Aarhus Bay, Denmark. Geochim Cosmochim Acta 58:5115-5129

Ullman WJ, Aller RC (1982) Diffusion coefficients in nearshore marine sediments. Limnol Oceanogr 27:552-556

Valdemarsen T, Kristensen E (2005) Diffusion scale dependent change in anaerobic carbon and nitrogen mineralization: true effect or experimental artifact? J Mar Res 63: 645-669

Valdemarsen T, Kristensen E, Holmer M (2009) Metabolic threshold and sulfide-buffering in diffusion controlled marine sediments impacted by continuous organic enrichment. Biogeochemistry 95:335-353

Westrich JT, Berner RA (1984) The role of sedimentary organic matter in bacterial sulfate reduction: the G-model tested. Limnol Oceanogr 29:236-249

Submitted: February 18, 2009; Accepted: October 28, 2009

Proofs received from author(s): February 1, 2010 